6-2002

\title{
An Examination of Gender Differences in Today's Mathematics Classrooms: Exploring Single- Gender Mathematics Classrooms
}

Celeste E. Dunlap

Cedarville University

Follow this and additional works at: http://digitalcommons.cedarville.edu/education theses

Part of the Science and Mathematics Education Commons

\section{Recommended Citation}

Dunlap, Celeste E., "An Examination of Gender Differences in Today's Mathematics Classrooms: Exploring Single-Gender Mathematics Classrooms" (2002). Master of Education Research Theses. 1.

http://digitalcommons.cedarville.edu/education_theses/1 


\section{AN EXAMINATION OF GENDER DIFFERENCES IN}

TODAY'S MATHEMATICS CLASSROOMS:

EXPLORING SINGLE-GENDER

MATHEMATICS CLASSROOMS

A thesis submitted in partial fulfillment of the requirements for the degree of Masters of Education

By

CELESTE ELIZABETH DUNLAP

B.A., Cedarville University, 1993

2002

Cedarville Univeristy 


\section{CEDARVILLE UNIVERSITY \\ SCHOOL OF GRADUATE STUDIES}

June 1,2002

I HEREBY RECOMMEND THAT THE THESIS PREPARED UNDER MY SUPERVISION BY Celeste Elizabeth Dunlap ENTITLED An Examination of Gender Differences in Today's Mathematics Classrooms: Exploring Single-gender Mathematics Classrooms BE ACCEPTED 'IN PARTIAL FULFILLMENT OF THE REQUIREMENTS FOR THE DEGREE OF Master of Education.

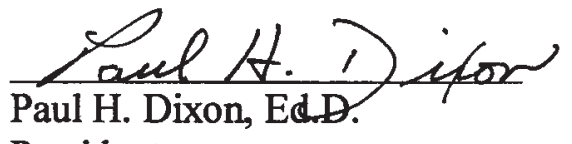

President

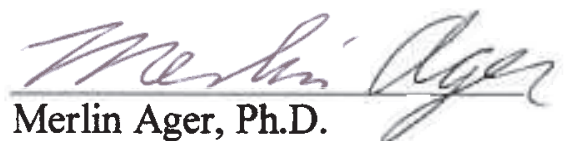

Dean, School of Social Sciences and Professional Studies

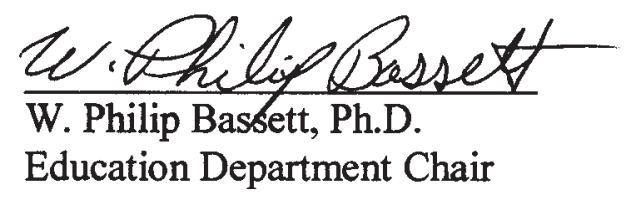

Huane R. Wool Dr. Duane R. Wood, Ph.D. Academic Vice President

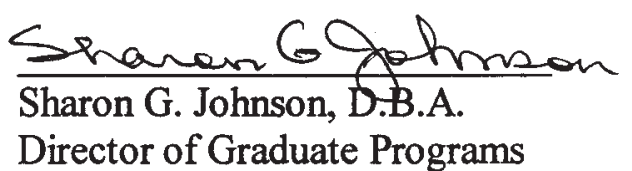

Director of Graduate Programs

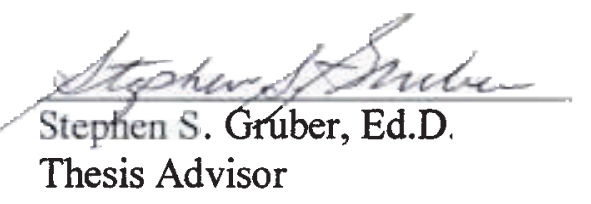




\begin{abstract}
Dunlap, Celeste Elizabeth. M.Ed. Education Department, Cedarville University, 2002. An Examination of Gender Differences in Today's Mathematics Classrooms: Exploring Single-gender Mathematics Classrooms

Much research identifies a gender gap in mathematics, and some research points to single-gender math classrooms as a solution to the math gender divide. The author conducted a seven week study in which she divided fifty fifth grade students into singlegender mathematics classes. She wanted to examine if single-gender math classes affected the math achievement and attitudes of her female students. Upon completion of the study the author found there was no statistical significance in the girls' achievement between a single-gender classroom and a coeducational classroom. There was a significant difference in the girls' perceptions as to how they best learn math.
\end{abstract}




\section{TABLE OF CONTENTS}

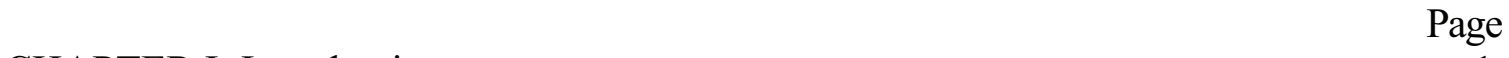

CHAPTER I: Introduction................................................. 1

CHAPTER II: Review of Literature........................................ 5

CHAPTER III: Procedures and Results.......................................... 51

Presentation of the Problem............................................ 51

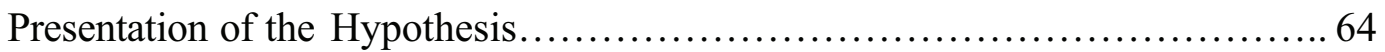

Subjects..................................................... 64

Variables........................................................ 65

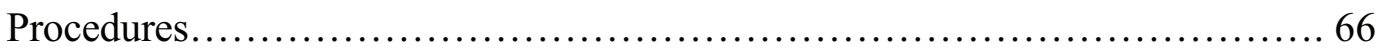

Results.......................................................... 68

CHAPTER IV: Summary and Conclusions.................................... 75

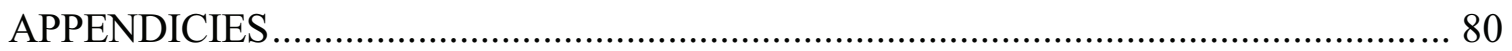

APPENDIX A....................................................... 80

APPENDIX B....................................................... 82

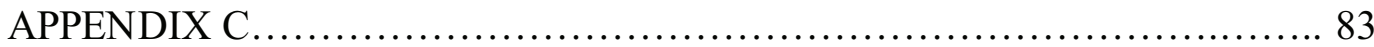

APPENDIX D.......................................................... 84

APPENDIX E....................................................... 85

APPENDIX F......................................................... 87

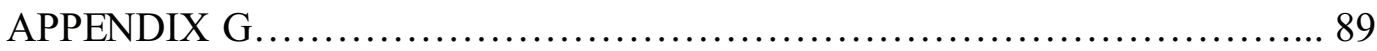

APPENDIX H........................................................ 91 
REFERENCES........................................................ 93

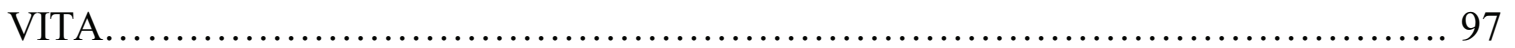




\section{ACKNOWLEDGEMENTS}

There are countless people that I must thank as this project comes to a close. First, I want to thank Dr. Stephen Gruber for giving so much of his time to answer so many of my questions during the course of this thesis. His guidance and help during these last months have been such a blessing.

I must also thank Dr. Ed Baumann who first introduced me to this topic in one of his courses. Dr. Baumann has been an incredible professor. Thank you for making me work hard, for challenging me to look at things differently, and for forcing me to expand my brain until it hurt.

I owe a huge thank you to my principal, Mr. Rick Schrenker, who gave of his time and energy in order to proofread my thesis. He has been a wonderful blessing and example of a godly servant. My teaching partner, Mrs. Julie Heyob, has been wonderful through this strenuous academic year. She has been such a help through my project by picking up extra tasks when she knew I was overwhelmed, by teaching all the girls in order for me to conduct my study, by being flexible, and by making me laugh when I really needed to laugh. Thank you so much, Julie. You have been such a help and are a wonderful teaching partner.

I also need to thank the fifth graders from Calvary Christian School for allowing me to use them for my project. Thank you for being so flexible and for being willing to take part in my experiment. It has been a blessing and a privilege to teach you this year. I must also thank my student helper, Lindsay Stephenson, who helped me so much this year by filing, doing my bulletin boards, and anything else I needed her to do in order to give me more time to work on this project. Thank you, Lindsay, for your joyful spirit and your servant's heart.

There have been many family and friends that have prayed for me and for this project along the way. They have also been a source of encouragement, and to them I owe a huge thank you: my in-laws, Rich and Eleanor Dunlap, Cheryl Ellington, and Mark and Becky Ziegler. Your love and friendship has been a blessing and means more to me than I am able to express.

And probably most of all, I need to thank my mother, Linda Barabas. Over the years she has challenged me to do all I can for the Lord. She has been an example of what a godly woman should be. She has instilled in me from the earliest moment the importance of a good education and has challenged me to reach for the stars. Without her constant prayer support, godly example, and wonderful words of encouragement, I would not even have dreamed of tackling a project as huge as this. Thank you, Mom. I love you!

Ultimately, I need to thank my Lord and Savior, Jesus Christ who has enabled me to complete this project by giving me His strength, His mercy, and His love. 


\section{DEDICATION}

I would like to dedicate this thesis to my constant encouragement and support, my best friend and my husband, Craig Dunlap. Without his encouragement, love, support, and prayers, I would not have been able to complete this monumental task. Thank you, Craig. I love you. 


\section{CHAPTER I: Introduction}

There is much discussion in today's schools concerning student achievement in mathematics. One specific area is the apparent gender gap between boys and girls in the area of mathematics. Most researchers agree that there is a gap; however, the debate wages on as to the degree of the gender gap and how much it is really narrowing. Some believe that girls have made great strides in the area of mathematics, have caught up with boys, and have caused the gap to narrow considerably, perhaps even closed it. Others believe that the gap still exists and is stronger than ever. Those who hold this view also feel that much must be done to ensure an equal education in mathematics between boys and girls at all grade levels.

There is also much debate as to what causes this gender divide and what should be done to eliminate it. Some researchers have claimed that unequal classroom instruction and biased instructors have caused this gap. Others blame society and the media for perpetuating gender stereotypes that encourage boys to excel in mathematics. Some take this idea further and identify the social pressures that young women feel in junior high and high school as the restricting force that prevents females from excelling in math. This debate over the root of the problem leads to a debate as to the solution of the possible gender divide in mathematics. Many feel that simply changing classroom instruction and providing positive female role models will encourage females in mathematics. Some feel that more direct instruction for faculty members and administrators as to how to combat gender inequity within the classroom is necessary in order to narrow the gap. Still others take a more drastic step and feel that single-gender 
math classes are the answer and will allow female students to excel and diminish the divide.

With so much debate as to the depth of the gap, the causes of the gender divide, and the possible solutions, it makes one wonder how does a fifth grade teacher determine the degree to which gender impacts math achievement? The author of this research thesis is a fifth grade teacher at a Christian elementary school in Northern Kentucky. Through her research, she hopes to determine the impact gender has in her fifth grade classroom on math achievement.

This is an important question. From early on in the school year, it was evident to the author that her girls do not like math. She has often noticed that very few of her female students regularly participate in math class, yet a majority of the boys are actively involved. She also often hears comments like "Math is hard," "I don't like math," and "I am not good at math" from her female students. These negative attitudes toward math at such an early age or at any age could affect these females and their future course selections and career choices. If unbalanced classroom instruction indeed plays a part in these negative attitudes toward math, the author hopes to recognize it in her own classroom and make it possible for all of her students to learn, receive equal instruction, and perhaps even grow to like math.

If indeed boys and girls are not receiving an equal math education, it should be addressed. An equal education is biblical. God created men and women equally. Genesis 
chapter two explains how God created Eve to be a help mate for Adam, someone to help him tend the Garden. There was an equality between the two that was established by God Himself. He provided equal opportunities for learning as Adam and Eve interacted with each other and their environment. Galatians 3:28 goes on to say that people, men and women, are one in Christ. God does not show favoritism based on gender. Neither should educators. Providing students with an equal education regardless of their gender is a must.

In order to answer the question of determining the degree gender impacts math achievement in a fifth grade classroom, this paper begins with an in-depth look at previously conducted research and writings on the topic of gender and mathe matics. It attempts to read a variety of viewpoints and various research conducted on the topic. It also attempts to identify differing solutions to the problem in order to give the reader a broader view of the potential solutions to possible differences between boys and girls in the area of mathematics. The author accessed most of the previously conducted research through the ERIC database, the OhioLink database, and the World Wide Web.

The researcher also seeks to identify any differences between male students and female students in relation to mathematics in a fifth grade classroom in a moderately sized private school in Kentucky. The author begins by conducting an attitudinal survey of mathematics within two fifth grade classrooms. It also compares third quarter grades to determine if there is a significant statistical difference between the boys and the girls. 
There has also been much debate surrounding single-gender schools. Title IX has prohibited single-gender public schools; however, there has been much research done in the area of private single-gender schools and with differing conclusions as to the benefit of both male and female students. Some feel that it is a wonderful way to reach female students. These researchers feel that it increases the confidence in females and allows them the chances to excel in nontraditional areas such as math and science. Some even go as far to say that Title IX should be revamped in order to allow public schools to offer single-gender math classes as an option to their students. Others oppose this idea, however, and claim that it would be a regressive step for women in general. Some feel that single-gender schools are of no benefit to females at all. Those who hold to this belief say that females do no better in single-gender schools: they simply like the schools better. Still others say that single-gender schools not only hurt females but males as well, because they do not allow students the opportunities to interact with the opposite sex and learn how to relate to them.

In response to this debate surrounding single-gender classrooms and the positive impact they may or may not have on female achievement in mathematics, a pretestposttest control design was completed by the researcher. This involved dividing the boys and girls into separate math classes and comparing grades prior to the separation and following the separation. There was also a survey given before the classes were divided and a survey following the treatment to determine any change in attitudes of the students. Scores were then compared to see if any significant statistical difference was present. 


\section{CHAPTER II: Review of Literature}

Many researchers feel that educators, administrators, and parents alike need to work toward gender equity in our schools. Fennema (1990) defines gender equity as the "set of behaviors and knowledge that permits education to recognize inequality in educational opportunities, to carry out specific interventions that constitute equal educational treatment, and to ensure equal educational outcomes," (Sanders, 1997). However, many researchers agree that Fennema's definition does not always occur in our schools and point to a gender gap in mathematics as a prime example. Twenty-one out of twenty-four sources used by the author hold to the belief that there is a gender gap in mathematics, to some degree, between males and females. The debate is concerning different aspects of the gender gap such as when it begins, how wide it is, if it is narrowing and by how much, the causes of the gap, and its effects.

Many of the answers to the above mentioned concerns have a lot to do with when the researchers originally conducted their research. Those who have conducted research in the area of a gender divide in mathematics before 1995 seem to feel that the divide exists and is very large. However, later and more recent research seems to point to the idea that the gap is narrowing, and girls are catching up with boys in mathematics. Although the author will attempt to focus her research on the elementary years, this review of literature will also examine any possible gender gaps at the high school, collegiate, and graduate levels. This review of literature will also attempt to outline any effects a mathematics gender gap could have on men and women as they enter their careers. 
In the early grades girls are ahead of or equal to boys on every standard measurement of academic achievement and psychological well-being (M. Sadker \& D. Sadker, 1994). Girls earn better grades than boys throughout school, yet their standardized test scores decrease as they get older (M. Sadker \& D. Sadker, 1994; American Association of University Women, 1999). In the early years, girls surpass boys on standardized math tests, but by middle school their scores begin a steady decline. Girls' math standardized test scores begin to descend in middle school when the boys pass the girls. Myra and David Sadker (1994), both of the American University, claim that achievement tests are a "male landslide" (M. Sadker \& D. Sadker, 1994). Sadker and Sadker (1994) studied fourteen different achievement tests and found that boys scored higher in eleven of them in the mathematics sections. In the Math I section of these achievement tests male scores were thirty-seven points higher. In the Math II section, males outscored females by thirty-eight points.

Wiest (2001) agrees that boys are ahead of girls in math and claims that girls are fine in math until they reach the middle school grades when their math achievement scores begin to decline. Schwartz and Hanson (1992) also agree and write that elementary girls are equal with elementary boys in their math achievement, but girls' achievement begins to decline in middle school. The Council for School Performance (CSP) (2001), an organization founded to examine math proficiency levels in the state of Georgia, found that the most critical time for the development of a gender gap in mathematics is during adolescence. This is especially crucial in the seventh grade, when girls' math performance begins to decline. Some feel that although the gap begins in 
middle school, it widens as students get older ("Girls Math Education,” 1998).

According to Sadker and Sadker (1994), the longer girls stay in school, the further behind they fall in mathematics. Sadker and Sadker write, "Females are the only group in America to begin school testing ahead and leave having fallen behind," (M. Sadker \& D. Sadker, 1994).

Yet, some would argue that the difference between standardized test scores of males and females throughout school is not statistically significant until much later in high school. In the 1992 report compiled by the National Assessment of Educational Progress, boys were identified as having a higher proficiency in mathematics, but a significant difference occurred only at the twelfth grade (CSP, 2001). In the 1997 report Condition of Education, also written by the National Assessment of Educational Progress (NAEP), there was no significant difference in the 1994 math proficiency scores between boys and girls at age nine years or at age thirteen years. However, at age seventeen females scored five points lower than boys in mathematics which, according to the NAEP, is equivalent to one-half year of schooling ("Girls Math Education," 1998).

Yet, the 1999 review of the NAEP report conducted by the American Association of University Women (AAUW) (1999) claims that the report showed a significant difference in mathematics scores for fourth grade where boys outperformed girls. The National Assessment of Educational Progress examination is voluntary and was given to a sample of fourth, eighth, and twelfth grade students in specific areas. The exam was used to test student knowledge in a certain area. The report also, according to the 
AAUW, identified the highest math scores as belonging to males: a larger proportion of males received the top NAEP scores. The study went on to say that the gender gap in mathematics increased in the later grades.

The original report compiled and published by the NAEP that was obtained and studied by the AAUW was not available to the researcher; however, the 2000 Math Report Card written by the NAEP and published in August of 2001 was available to the researcher. The report reviewed the progress of mathematics scores over the last decade. Once again, the tests were administered to a sample group of fourth, eighth, and twelfth graders. The results showed that both boys and girls increased their scores steadily since 1990. Eighth grade boys also increased their mathematics scores since 1996. However, the apparent increase of the girls' mathematics scores since 1996 was not statistically significant. At the twelfth grade level, there was also an increase in math scores from 1990 through 1996 for both boys and girls, but from 1996 through 2000 there was a decrease in mathematics scores for both males and females. The decline in scores, however, was not statistically significant for the males (NAEP, 2001).

The 2000 NAEP report also compared boys and girls in relation to their mathematics scores. Fourth grade boys did perform better than girls in mathematics, but the difference in scores was not statistically significant. Eighth and twelfth grade males had significantly higher scores than females (NAEP, 2001). 
The report went on to determine if each gender was performing at or above a basic proficiency level. The test used the following rankings from lowest to highest: below basic, basic, proficient, and advanced. In fourth grade, both boys and girls increased at the basic level since 1990, and there were also gains in the number of students who achieved the proficient level. At the eighth grade, boys significantly increased at all the levels. The girls also increased at all levels, but the increase in levels was not statistically significant. At the twelfth grade level, both males and females increased levels significantly since 1990 . When comparing the two genders and their levels, there is a significant difference between males and females at grade eight and grade twelve in 2000. There is a greater percentage of males at all three grade levels who performed at or above the proficient level and at the advanced level than females in 2000 . There was no statistical significance between males and females when comparing from the basic level and higher for the three grade levels (NAEP, 2001).

Along with their review of the NAEP report, the AAUW also conducted a review of the Third International Mathematics and Science Study (TIMSS). This is an achievement test that was given to one-half million fourth, eighth, and twelfth graders in forty-one nations during the 1995-1996 academic year. The analysis of this study was released in February of 1998. It showed, according to AAUW, that the gender gap in the field of mathematics increases with age. A gender gap in mathematics is nonexistent in fourth grade, but by twelfth grade, males had a significantly higher average achievement than females in mathematics. There were also significant gender gaps in "special" fields, which would include higher, more advanced mathematics classes (AAUW, 1999). 
In 1996 The Educational Testing Service (ETS) (2001) conducted a study which attempted to identify any gender differences within various racial and ethnic group s. The Educational Testing Service found that fourth grade males outscored females in math. This difference was only found in White students. They also claim that there were no differences between males and females in mathematics at grades eight and twelve in any other ethnic or racial group. There was no alpha level given to identify at what level the scores were not statistically significant. The conclusion made by ETS was that there are little gender differences within ethnic groups in the area of mathematics.

Even though there seems to be much debate as to the size of the gender gap, many researchers feel that the gap is narrowing (The Women's Freedom Network, 1998; D. Sadker, 1999; AAUW, 1999; CSP, 2001). The concern, for some researchers, seems to be turning more toward the gap that is appearing in the types of math courses that male and female students are taking (CSP, 2001). David Sadker (1999) identifies that although female enrollment in math classes has increased in the 1990s, there are still courses of study that are gender specific.

Sadker and Sadker (1994) go on to say that boys and girls take almost the same number of mathematics courses, including algebra and geometry, but more boys go on to study calculus while girls drop out of the mathematics track. Another example can be seen in a study of fourteen schoo-to-work programs. In this study over ninety per cent of the females enrolled followed a few traditionally female programs such as teaching and education and office technology (D. Sadker, 1999). Karp and Shakeshaft (1997) make a 
similar statement. They say that seventy per cent of female vocational high school students study traditional female fields.

The Association of American University Women's report (1999) also identifies that although girls' participation in math classes is improving, females are still less well represented in higher-level math classes. According to the AAUW's report, female enrollment is up in mathematics classes, and the difference in the course patterns of boys and girls is decreasing. The average number of math courses females take is narrowing, but there are gender differences that remain in the types of math courses taken. There are more girls enrolling in algebra, geometry, pre-calculus, trigonometry, and calculus. However, girls are more likely than boys to end their high school math careers with Algebra II. The AAUW writes, "Stopping a math education at this level can close the door on future studies, scholarships, and careers," (AAUW, 1999).

The AAUW's review of the study done by the Council of Chief State School Officers and the 1994 High School Transcript Study found that both males and females take 3.5 high school math courses (AAUW, 1999). (The 1994 study was the most recent year of data available at the time.) However, a course by course study shows that gender divisions remain. More male high school graduates than female graduates took the lowest level math courses (basic math and general math), while there are more females taking algebra and geometry. The study also found that there are equal proportions of females and males taking pre-calculus or calculus before leaving high school (AAUW, 1999). 
The study also compared the female enrollment in mathematics classes over a four year period. More girls entered Algebra I, Algebra II, geometry, pre-calculus, and calculus in 1994 than in 1990. In 1994, there were roughly an equal number of girls and boys who took pre-calculus, trigonometry, and statistics/probability (AAUW, 1999). According to American College Testing, Incorporation (ACT, Inc.), (a nonprofit organization best known for its college admissions testing program), they also identified more females than males taking geometry and Algebra II. ACT, Inc. also claims that the proportion of girls taking trigonometry and calculus has increased from seven per cent to nine per cent since 1987. By 1997, female enrollment in geometry has also increased by eight per cent, and Algebra II enrollment has increased by fifteen per cent (AAUW, 1999).

According to the NAEP's Condition of Education (1997), an equal number of males and females take advanced mathematics classes in high school. The female enrollment in math classes has increased so much since 1994 that females are now more likely to take Algebra II in high school than males. Females are also just as likely to take calculus in high school as males ("Girls Math Education," 1998). The Educational Testing Service in their 2000 report claimed that the last decade saw females closing the gap in math by taking four or more years of math. According to ETS (2001), in 1999 White, Black, and Asian/Pacific Islander females pulled even with males in the number of years they are taking math. There still remains a gap of between three and four points between Hispanic males and females, however. 
Even though female enrollment in higher level mathematics courses has significantly increased, girls are significantly more likely than boys to end their high school math careers with Algebra II. Fifty-three per cent of females choose to end their high school math careers with Algebra II compared to only forty-seven percent of males (AAUW, 1999). Kundiger and Larouche conducted a study of twelfth grade girls in fifteen countries. They found that in twelve out of the fifteen countries, females performed lower than males in mathematics classes, and females took more "rudimentary" math courses than their male classmates. Often females dropped mathematics altogether (Schwartz \& Hanson, 1992).

According to Karp and Shakeshaft, "mathematics coursework is the "critical filter' in career opportunities," (Karp \& Shakeshaft, 1997). Karp and Shakeshaft (1997) feel that because females do not take a full mathematics course load in high school, they do not have the prerequisites necessary to many careers. Without these prerequisites, eighty-two potential career paths will be eliminated. Levi (2000) also agrees that males and females are taking similar math classes. Levi goes on to say that females and males achieve similar math scores throughout the school years (kindergarten through twelfth grade). Levi does claim, however, that males participate in mathematics after high school far more often than girls.

What seems to intrigue researchers is how females can achieve equal or higher grades in their courses than males, yet not score as high as males on high stakes tests (M. Sadker \& D. Sadker, 1994; Karp \& Shakeshaft, 1997; The Women's Freedom Network, 
1998; AAUW, 1999; D. Sadker, 1999). There does seem to be much agreement that males score higher than females on high stakes tests such as the Scholastic Aptitude Test (SAT), the American College Testing examination (ACT), and the Graduate Record Examination (GRE) (M. Sadker \& D. Sadker, 1994; AAUW, 1999; D. Sadker, 1999; ETS, 2001). In 1993 the NAEP identified males as scoring an average of forty-five points higher than females of the SAT (CSP, 2001). When Sadker and Sadker published their book Failing at Fairness: How Schools Cheat Girls in 1994, they identified males as typically receiving scores that were fifty to sixty points higher then females on the mathematics section of the Scholastic Aptitude Test. Sadker and Sadker (1994) make the claim that a high school girl with an A+ grade point average typically scores 83 points lower than a boy with an A+ average. Sadker and Sadker go on to say that females also score lower than males on the mathematics section of the ACT by one full point. They also claim that females score an average of eighty points lower than males on the quantitative section of the GRE.

According to Karp and Shakeshaft (1997), in 1995 males continued to score higher than females on the mathematics section of the SAT. The average male score in the mathematics section was 503 while the average female score was 463 . They also found that since 1992 those who scored very high on the mathematics section (a score between 750 and 800 ) were primarily males. Males placed in this category four times more often than females. Karp and Shakeshaft claim that between 1982 and 1995 males scored an average of 45.5 points higher than females on the mathematics section of the SAT. 
The ETS report (2001), that attempted to identify differences in gender within racial groups, also found differences in male and female math performances on high stakes tests. According to ETS, males in all racial and ethnic groups outscored females on the SAT I Mathematics Test. The average gender gap in all the ethnic groups was between thirty-two and thirty-eight points. The lowest point difference was found between Black males and Black females with only nineteen points separating the scores. The greatest point difference was between Latino males and females with a spread of fifty- five points.

ETS (2001) also found that within all the ethnic/racial groups males outscored females on the GRE Quantitative Mathematics Test. For this test, ETS found that White males and females had the largest gap of seventy points, while Black males and females had the smallest gap of all the ethnic/racial groups with forty-three points.

The 1997 NAEP report states that males were still scoring higher than females on the mathematics sections of the SAT exam in mathematics ("Girls Math Education," 1998). In 1999 Sadker wrote that tests like achievement tests and the SAT still show the gap between males and females in the area of mathematics. Even though the overall scores on the SAT have declined in recent years, boys still outscore females in the mathematics section of the SAT.

In 1999 the AAUW published their findings about gender and academics in Where Schools Still Fail Our Children. They, too, claim that males have higher standardized test scores than females. They found that the mathematics scores have 
increased for both males and females on the SAT; however, the gender difference has not decreased. They also have found that males score higher than females on the mathematics section of the ACT.

There are a few theories as to why males outperform females on these high stakes tests, even though females achieve equal or higher grades than males in school. Sadker and Sadker (1994) attribute some of the difference to the way males and females take tests. Boys do better on "beat-the-clock pressure cooker" timed tests like those created by SAT. Females, however, perform better on tests that are not timed. Sadker and Sadker also feel that the type of test also impacts the scores for males and females. Boys do better on multiple-choice tests, while females do better on essay questions.

One of the major concerns over the gender differences found in the high stakes tests, especially the mathematics section, is the impact these scores have on college acceptance and scholarship opportunities. Karp and Shakeshaft (1997) identify lower SAT mathematics scores as the main reason fewer females are admitted to prestigious colleges. Karp and Shakeshaft also feel that females lose many scholarships because of their lower SAT mathematics scores (Karp \& Shakeshaft, 1997). There are over one hundred scholarship programs that rely on standardized test scores to select recipients. High test scores cause scholarship money to be awarded at eighty-five per cent of private colleges and at nearly ninety per cent of public institutions. They can also result in state grants (M. Sadker \& D. Sadker, 1994). One such test is the PSAT which allows students to win many scholarships, including the National Merit Scholarship (M. Sadker \& D. 
Sadker, 1994; AAUW, 1999). Boys score higher on this test than girls. Two out of three finalists for the National Merit Scholarship are male (M. Sadker \& D. Sadker, 1994). ETS, according to Sadker and Sadker, is familiar with this major difference in male and female scores. To reduce the gender gap in mathematics, they count the verbal section twice and the mathematics section only once. Boys still outscore girls, however, on both sections. Without this adjustment, claim Sadker and Sadker, the gap would be even greater (M. Sadker \& D. Sadker, 1994). ETS claims that the difference in math scores is not a result of the tests but of a deeper educational problem. One problem ETS sights is the fact that boys take more high school mathematics classes than girls, which contributes to higher math test scores (M. Sadker \& D. Sadker, 1994).

Despite the apparent challenges females have in taking high stakes tests and possibly receiving less scholarship money, women presently make up the majority of post-secondary students. In 1994, women made up fifty-three per cent of the enrollment in post-secondary institutions (M. Sadker \& D. Sadker, 1994). As of 1999, however, women made up sixty per cent of college students. The year 1999 also saw fifty-seven per cent of the Bachelor of Arts degrees go to women. This is a definite increase from 1970 when they received only forty-three per cent of the Bachelor of Arts degrees and only twenty-four per cent of the degrees in 1950 (D. Sadker, 1999). Sadker (1999) makes the prediction that if this increase continues, by the year 2008, women will outnumber men in undergraduate and graduate courses 9.2 million to 6.9 million. 
However, many researchers feel that there remains a gender divide in the types of classes men and women take and the careers they choose for themselves. College females are still highly represented in fields that have been traditionally female domain such as languages, music, drama, and dance. Males are still seen more in the computer science fields as well as physics and engineering (D. Sadker, 1999). The "hard" sciences are still a male domain. Seventy percent of those enrolled in the chemistry, physics, and computer science departments at the collegiate level are male. The "soft" sciences are still largely the female domain. Ninety per cent of the Bachelor degrees in home economics went to women along with sixty-seven per cent of the liberal arts degrees and eighty-four per cent of the health science degrees (M. Sadker \& D. Sadker, 1994).

According to the NAEP, male and female high school seniors are equally likely to expect a career in math. Yet, at the post-secondary level, women are less likely than men to earn a degree in math ("Girls Math Education," 1998). Karen Arnold conducted a study in which she tracked high school valedictorians and salutatorians for a decade. This included forty-six women and thirty-five men from schools throughout Illinois. Women continued to earn high grades in college, even slightly higher than men. Yet, they saw themselves as less competent, and they abandoned careers in science and math (M. Sadker \& D. Sadker, 1994).

The NAEP also claims that in 1994 men were twice as likely than women to earn a Master's degree in math (“Girls Math Education," 1998). Wiest (2001) makes a similar claim when she writes that women are less likely than men to earn a degree in 
mathematics. According to a 1995 study done by Sanders and Peterson (1999), only forty-seven per cent of the Bachelor's degrees awarded in mathematics went to women. Only forty-two per cent of the Master's degrees in mathematics went to women. Sadker and Sadker (1994) write that most doctorates in business and engineering go to men (seventy- five per cent and ninety-one per cent respectively).

The Women's Freedom Network (1998), an organization devoted to gaining equality for all people, claims that in 1994 women obtained forty per cent of the professional degrees awarded that year. Women also received forty-three per cent of the law degrees and almost forty per cent of the medical degrees awarded. The Women's Freedom Network goes on to say that women received a majority of the veterinary medicine (sixty- five per cent), optometry (fifty-five per cent), and pharmacy (sixty-five per cent) degrees. Along with that, women received forty per cent of the doctoral degrees, and out of the forty per cent awarded, twenty-two per cent were in mathematics and physical science.

The Women's Freedom Network (1998) agrees with many others that there is a gender gap in mathematics, but they claim that "the number of people affected is too small to affect many people's lives." They feel that women have made "astonishing educational progress" which can be seen in the number of math doctorates that were awarded to women in 1994. One hundred forty-six women received math doctorates in 1994 while the number of men receiving math doctorates totaled 450 . 
Another concern many researchers share is voiced by Sadker and Sadker when they write that many female students are less likely to take courses that lead to "lucrative and prestigious careers," (M. Sadker \& D. Sadker, 1994). According to the NAEP, female college graduates earn less on average than male college graduates. The NAEP says that this difference in earnings may be related to the types of occupations men and women generally enter. They go on to say that the highest salaries can be found in the mathematics, computer science, and engineering fields which are dominated by men ("Girls Math Education," 1998). Ten of the highest ranked jobs in the twenty-first century are directly related to math. Ninety per cent of the workforce which males dominate are careers that are related to math and science (Karp \& Shakeshaft, 1997).

Karp and Shakeshaft (1997) concur that males have higher salaries than females. As of 1992, the average male college graduate made $\$ 11,221$ more than the average female college graduate. According to Karp and Shakeshaft, the average yearly income of a female college graduate in 1992 was only $\$ 1,300$ more than the average yearly income of a high school male graduate. According to Sadker (1999), as of 1999, full time female workers with a Bachelor of Arts degree made, on average, $\$ 4,708$ more than male full time workers with only a high school diploma. This would mean that women with college degrees earn, on the average, $\$ 20,000$ less than men with college degrees.

Karp and Shakeshaft (1997) go on to write that the increase in salaries that males see as they further their careers is greater than it is for females. For males, the average starting salary is $\$ 29,000$. At middle age, their average salary has increased to $\$ 41,000$ 
and then decreases to an average of $\$ 20,000$ for those still in their careers after sixty-five years of age. For females, they start out at an average of $\$ 22,000$ and are still averaging $\$ 22,000$ during middle age. If they are still in their careers after age sixty-five, their average salary decreases to $\$ 6,800$.

The Educational Testing Service (2001) also identifies men in all ethnic/racial groups as earning more than women. The largest difference was found between White males and females. In 1997 the average yearly income for a male high school graduate was $\$ 29,298$ compared to a female's average yearly income of $\$ 17,166$. White male college graduates also had the largest income advantage over White female college graduates. White male college graduates had an average yearly income of $\$ 51,678$ compared to a female's average yearly income of $\$ 30,041$.

Many researchers feel that mathematics impacts every aspect of education and life from elementary school right up through career choices that men and women make. The gender gap in mathematics can impact the decisions that many students make during high school and possibly later in life. Many wonder, then, what exactly causes this apparent gender divide in mathematics. There is much speculation as to the answer to that question.

An apparent recurring theme as to a cause of the possible mathematics gender divide relates to the type of instruction boys and girls receive in school, as early as elementary school. In 1992, the AAUW published a report in How Schools Shortchange 
Girls. In this report, the AAUW identified some inequalities that they found in classroom instruction. They claimed that boys received more teacher attention than girls. They also claimed that boys received more complex and challenging interaction with teachers than girls did and that boys received more constructive feedback than girls. The AAUW also found that teachers gave more wait time before calling on boys to respond than the amount of time that they gave girls to answer. The AAUW also felt that this gender bias in the interaction between the teacher and students was found in all subject areas, but the greatest bias was found in the math and science classrooms (AAUW, 1999).

Since 1992, there have been many studies done to determine the validity of the AAUW report and to determine the degree of unbalanced classroom instruction. Sadker and Sadker agree with the 1992 AAUW report. They claim that teachers interact with males more frequently, ask male students better questions, and give males better feedback which they define as more precise and helpful feedback. According to Sadker and Sadker, girls are the "invisible members of classrooms," (M. Sadker \& D. Sadker, 1994; D. Sadker, 1999).

The Women's Freedom Network (1997) does not agree. They feel that there is no evidence that the answers boys call out are accepted and that girls are simply told to "raise your hand if you want to speak." The Women's Freedom Network also feels that there is no support that girls receive less constructive attention, are called on less often, or that boys are given more time to answer before the teacher moves the discussion along. 
Yet, Sadker and Sadker (1994) and Smith (1996), who have conducted research on student-teacher interactions within the classroom, claim that boys call out significantly more often than girls. Sometimes, what they call out has little or nothing to do with what is being taught at the time. Yet, teachers respond to them. If girls call out, they are told to raise their hands (M. Sadker \& D. Sadker, 1994). Boys in elementary and middle school call out answers eight times more often than girls; yet, teachers often continue to encourage more boy participation (Family Education Network, 1999). Schwartz and Hanson have come to similar conclusions. They feel that teachers who focus on participation as an indicator of learning focus on males more than females, because males participate more in class. Schwartz and Hanson (1992) reviewed a study done by Redpath and Claire (1989). Redpath and Claire concluded that boys between the ages of nine and eleven had three times as many opportunities to speak than girls.

The American Association of University Women (1999) says that teachers give boys more wait time than girls. Teachers typically give students less than one second to answer. Girls are more concerned with getting the correct answer, so they take longer to answer. According to the AAUW report, teachers who do not give long wait times not only do girls a disservice but also do a disservice to boys by not teaching them selfcontrol, listening skills, and respect for others.

It seems that unbalanced classroom instruction does not stop at the high school level. In a study conducted by Sandler and Hall, they found that professors gave males more nonverbal attention. For example, professors gave their male students more eye 
contact, longer wait times, and were more likely to remember their names than the females in their classes (M. Sadker \& D. Sadker, 1994).

Sadker and Sadker (1994) conducted a study in which they observed students in a variety of classroom situations. They concluded that out of twenty-five students, two or three will be "green-arms." They define "green-arms" as students who have their "hands up in the air so high and long that the blood could have drained out," (M. Sadker \& D. Sadker, 1994). Sadker and Sadker also call these students "stars" and claim that ten per cent of all students are "green-arms," (M. Sadker \& D. Sadker, 1994). In an unpublished doctoral dissertation written by Dolores Gore (1981), more often these stars ("greenarms") are males. According to Gore, for every eight boy stars, there is one girl star (M. Sadker \& D. Sadker, 1994).

In this same study done by Sadker and Sadker (1994), they categorized and then ranked the types of students who received the most teacher attention. The ranking, from the highest amount of teacher attention received to the lowest amount of teacher attention received went first to white males, then to minority males, followed by white females, and finally to minority females.

In a 1998 study done by Matthews, Binkley, Crisp, and Gregg (1998), they, too, found that teachers called on boys more frequently than girls. They also observed, in a fifth grade classroom, that teachers gave greater feedback to boys, and they punished boys more severely than girls for the same infractions. They also noticed that in mixed- 
gender groups, boys seemed to take the leadership roles while girls agreed with the boys' decisions. In this same classroom, the authors of the study observed an activity where students had to create machines. When the teacher began calling on students to share their machines or to answer questions, the teacher called on boys thirty-one times and on girls only thirteen times. The authors also write that after two days of classroom observation, they knew three boys' names and two girls' names. They also observed that boys shouted out answers more frequently than the girls, and the boys' names were on the behavior chart more often than the girls' names.

Sadker and Sadker (1994) feel that one reason teachers spend more time with boys than with girls is due to the increased difficulty involved in managing boys and their behavior. Girls receive less time and help, because they pose fewer challenges. The Women's Freedom Network (1997) would agree with this as would the AAUW (1999). They claim that more attention goes to boys but claim that it is negative attention or is a result of necessary disciplinary action.

The American Association of University Women reviewed many studies concerning unbalanced classroom instruction. According to the AAUW report, Carole Shmurak and Thomas Ratliff studied eighty middle school classrooms and found the math classes to be the most equitable in student participation. Melody D'Amrosio and Patricia Hammer studied forty-one Catholic elementary schools. They found that "male students receive more attention in all categories of teacher-student interaction (praise, acceptance, remediation, and criticism)," (AAUW, 1999). Mary Bendixen-Noe, Lynne 
Hall, Sandra Zaher, and Carol Shakeshaft reached similar conclusions (AAUW, 1999). The original studies were not available to the author.

The Council for School Performance (2001) also found that teachers gave more attention to their male students than their female students. The Council felt that teachers called on boys more often and encouraged boys more than they did the girls. They also felt that boys dominated conversations more often and asked more questions than girls. The Council even identified the difference in the types of affirmation the students received. Girls were praised for their neatness or politeness, and boys were praised for their abilities. Karp and Shakeshaft (1997) came to a similar conclusion. They feel that girls are praised for following rules, conforming to a certain standard established by the teacher, their appearance, their silence, and their neatness. Sadker and Sadker (1994) would also agree with this. They feel that boys are praised for the intellectual quality of their ideas, while girls are praised for following the rules of form.

Karp and Shakeshaft (1997) also identify unbalanced classroom instruction as a detriment to the mathematical achievement of female students. They, too, feel that boys dominate classroom communication at all grade levels in all types of communities and in all subject areas. Karp and Shakeshaft believe that boys are called on more often, interact with the teacher more often, are asked complex and open-ended questions more often, and are called on to use abstract reasoning more often than girls. According to Karp and Shakeshaft, girls are asked rather basic recall questions. If girls are unable to give the answers, the girls are often given the answers. Boys, on the other hand, are given eight 
times more information as to how to solve the problem. Tschumy (1995) agrees that boys tend to dominate classroom discussions. She feels that girls receive less active instruction than boys. This includes both the quality and quantity of instruction.

Bauer concurs with the previously mentioned research on unbalanced classroom instruction. She, too, feels that girls are generally invisible in the classroom. Bauer also feels that teachers interact more with boys than girls by reprimanding them more, answering more of their questions, elaborating on their comments more often, and helping them with their work more often. Bauer also feels that boys tend to control conversations, ask more questions, and receive more praise and feedback as do their girl classmates. Bauer goes on to identify that the fact that girls receive less feedback has a powerful effect. Receiving feedback, according to Bauer, allows students to grasp the subject matter. By not providing girls with the appropriate feedback, Bauer feels that teachers imply that girls cannot solve problems on their own, that they cannot tolerate constructive criticism (Bauer, 1999). Teachers often try to "soften the blow" for boys as they criticize their work. Girls receive even less communication (M. Sadker \& D. Sadker, 1994). The AAUW (1999) report claims that many teachers do not want to hurt girls or discourage them by providing them with constructive criticism or feedback. Yet, girls do not learn to respond to criticism if they do not receive it in elementary school.

Bauer (1999) goes on to identify that girls infer that they are not worthy of wait time. Teachers typically give .9 second to answer. Generally, boys have more time than girls. According to Sadker and Sadker (1994), increasing the wait time is one of the most 
positive and powerful things a teacher can do. David Sadker (1999) continues to agree with Bauer. He writes that increased teacher attention to the boys contributes to enhanced student performance. According to Sadker, the boys reap the benefits, while the girls lose out.

Sadker and Sadker (1994) believe, as do Matthews, Binkley, Crisp and Gregg (1998), that students pick up on this unbalanced instruction. Matthews, Binkley, Crisp and Gregg quote a fifth grade girl in their study as saying, "When boys shout out it's okay, and when girls shout out it's not," (Matthews, Binkley, Crisp \& Gregg, 1998). Sadker and Sadker (1994) summarize a survey done by Glamour (1992) which asked teenage girls a series of questions. Of those who responded, seventy-four per cent claimed they had a teacher who was biased against females and paid more attention to the boys. They also said that math class was where most inequities occur. Fifty-eight per cent identified math class as their most sexist subject. Sanders and Peterson write, "The type of experiences girls have in middle school and high school math classes is often the critical filter than can lead to declining female enrollments and negative attitudes at the post-secondary level," (Sanders \& Peterson, 1999).

The Women's Freedom Network disagrees (1997). They hold to a 1990 poll of children that was commissioned by the AAUW which contradicts what many researchers believe about students' perception of classroom instruction. In this poll, eighty-one per cent of the girls and sixty- nine per cent of the boys felt that their teachers tho ught that the girls were smarter. Sixty per cent of those polled felt that teachers pay more attention to 
girls and call on them more. The poll also identified that there was no difference in the perceptions of boys and girls in regards to how often teachers called on them. The Women's Freedom Network goes on to write that there were an equal number of boys and girls at all grade levels who said that teachers listened to them and that they liked to ask and answer questions.

When examining classroom instruction in order to determine if an unbalance exists, one must also examine teacher bias and learned helplessness as possible causes to a mathematics gender divide. In the AAUW report (1999), the observation is made that girls are more likely to have their abilities in math overlooked by their teachers. This is especially common in schools where students are tracked on the basis of their ability levels. Once again, the AAUW reviewed studies done in relation to teacher bias.

Marueen Hallinan found that the higher the track level, the better the students' academic status, self-esteem, and motivation to learn. Braddock and Slavin, according to the AAUW report, wrote that "being in the low track in eighth grade slams the gate on any possibility that a student can take courses leading to college," (AAUW, 1999). Reis and Callahan found that male teachers, in particular, stereotype girls and their talents. These inaccurate judgments may deter many girls from persevering in mathematics (AAUW, 1999).

Learned helplessness on the part of girls is also a concern for many researchers. Learned helplessness occurs when teachers "do for" girls instead of teaching them "how to." In a study done over twenty years ago by Serbin and O'Leary, it was found that 
teachers were less likely to offer explanations and directions to girls as to how to do things. Instead, they would do things for them (M. Sadker \& D. Sadker, 1994). Sadker and Sadker call this process "short-circuiting," (M. Sadker \& D. Sadker, 1994). A study done in the 1990s by Janzen, however, proved that little had changed over the years. Janzen found that teachers still did things for girls but chose to talk boys through and teach them the process. For example, in the study conducted by Janzen, a class of seven Hispanic boys and eight Hispanic girls was studied over an academic year. At the beginning of the year both boys and girls needed help playing a tape in the VCR. The teacher's aide did it for the girls but talked the boys through the process. At the end of the year, Janzen found the boys could play the tapes themselves, but the girls still had to have the aide help them (M. Sadker \& D. Sadker, 1994).

Sadker and Sadker write, "Girls do not think adults expect them to be able to do things because throughout school they are interrupted in attempts to accomplish things on their own,” (M. Sadker \& D. Sadker, 1994). According to Sadker and Sadker (1994), girls eventually learn to "short-circuit" themselves by hanging back and letting the boys take over. After a while, this short-circuiting becomes internalized. When a teacher does for a girl instead of teaching her how to do something, her education is turned off. Teachers are susceptible to this very thing. Teachers are more likely to teach learned helplessness by doing tasks for girls when they have difficulty with a task instead of scaffolding them through the process (Karp \& Shakeshaft, 1997). 
Many researchers go beyond the classroom in order to determine a possible cause of this gender divide in mathematics. Another factor many consider as a potential cause is society in general. This would include, students' families, teachers, peer influences, and society at large. The Council for School Performance (2001), for example, feels that gender socialization begins early on at the family level.

Tiedemann (2000) found that parents hold "gender differentiated views" of their children beginning at an early age. Parents are more "gender differentiated" than "objective" when it comes to identifying their children's actual mathematical performance. Tiedemann found that parents did have an affect on their children's selfassessments in regards to their math performance. Parents who held a gender stereotype not only affected their own assessment of their child's abilities but also influenced how their child assessed his or her own abilities. At the high school level, Tiedemann also found that parent gender stereotypes negatively affected student math performance. Eccles and Arberton (1993) did not find that gender significantly affected parents' views of the math abilities in their younger children (the study used the parents of kindergarten, first, and third grade students). They concluded, therefore, that the gender-related effect of parent perceptions of math abilities does not emerge until children are older (Tiedemann, 2000).

Tiedemann (2000) found that parents' gender stereotyping did indeed predict how a child would assess his or her own mathematical ability. If parents thought in gender stereotypes, they assigned lower math abilities to their daughters. If parents did not think 
in gender stereotypes, there was no significant difference in their view of their child's ability in math. Tiedemann concluded that parents' stereotypes interacted with the gender of the child which in turn predicted the beliefs the parents held of the child's math ability. Parents' beliefs then influenced the child's self-concept in his or her own math ability. Although the boys and girls in Tiedemann's study had the same grades, the boys had higher math ability beliefs than the girls. Students' self-perceptions were influenced by parent and teacher evaluation. (In the sixth grade math classrooms that Tiedemann used in the study, teachers believed that the boys were more talented in math than the girls, even though there was no gender difference in their standardized test scores.) Tiedemann found that this increased with the age of the student. Parent gender stereotypes influenced the beliefs that parents held concerning the abilities of their child in math. These beliefs directly influenced the child's own perception of his or her mathematical abilities. Both the parent belief and the child's self-perception influenced the child's achievement.

Schwartz and Hanson (1992) and the Council for School Performance (2001) agree with Tiedemann that parents directly influence their children's attitudes toward mathematics. They feel that parents do not support their girls in math but direct their girls' interests elsewhere, while giving all their support to their sons. They continue to add that often the attitudes of teachers and male classmates reinforce parents' messages. Tschumy (1995) offers another example. When parents were asked to picture an intelligent child, fifty-seven per cent of the women and seventy-one per cent of the men pictured a boy. Sadker and Sadker (1994) also feel that both parents and teachers 
underestimate the intelligence levels of girls. Teachers, they claim, believe that boys are smarter in math, even at an early age, despite the fact that both boys and girls receive equal scores in math, and girls are getting better grades. Sadker and Sadker state that many adults believe that boys have an innate mathematical ability, and that girls must work at math. With the influences of parents and teachers, girls learn to underestimate their mathematical abilities.

For females, perhaps an even stronger influence than parents and family are their peers. A study done by Allison Ryan and Dr. Paul Pintrich, both of the University of Michigan, found that students, particularly girls, feel that social pressures have an impact on their achievement. According to Ryan and Pintrich, their study found that young people feel that, "looking stupid is the number one thing to avoid—even if it means falling behind in class," (Bryan, 1997). Ryan and Pintrich found that students who were not doing well were the least likely to ask for help. They also found that the more competitive students were more likely to worry about what others thought about them than the students who were concerned about their own learning and understanding (Bryan 1997).

Tschumy (1995) claims that there are different expectations that boys and girls have for themselves within the classroom. Boys can be smart in class and take on leadership roles, but girls can not act "too smart, too strong, or too confident," (Tschumy, 1995). Sadker and Sadker (1994) claim that, in today's schools, adolescent girls feel that they can not be bright and popular at the same time, so they opt out of higher level math 
courses, which can prevent later careers in math, science and technology. Sadker and Sadker call this a girl's "first career move," although girls are completely unaware of it. In a study done by Donna Eder and Stephen Parker, they observed 190 sixth, seventh, and eighth grade girls in a midwestern middle school. They found that very bright female students denied their intelligence (M. Sadker \& D. Sadker, 1994).

Some feel that even society at large has done its share to create and perpetuate the gender divide in mathematics (Bauer, 1999; Schwartz \& Hanson, 1992; Sanders \& Peterson, 1999; AAUW, 1999; Wiest, 2001; CSP, 2001). Some feel that our society continues to contribute to the gender stereotypes felt by so many, including girls. Many girls still feel that math is a "male subject." Girls learn this early on, and it could contribute to the fact that girls are less interested in math, and, therefore, take less math classes in high school (CSP, 2001). Girls have been taught their gender roles by society. Society expects girls to not be aggressive but to be compliant and quiet (Schwartz \& Hanson, 1992; CSP, 2001). Girls are likely to ask questions, acknowledge comments of previous speakers, and not interrupt others when they are speaking. Teachers are apt, however, to treat their contributions with less authority and, therefore, pass on negative expectations (Schwartz \& Hanson, 1992).

The AAUW (1999) also feels that society impacts girls. They feel that society has shaped opportunities and expectations for both genders. This social expectation can be seen inside and outside the school and influences the way girls see themselves and how their parents and other adults see them. 
Yusuf (1995) claims that the gender role stereotypes that are presently found in society, within the family, and in schools influence girls' math achievement in a negative way (Wiest, 2001). Wiest (2001) feels that schools contribute to the problem rather than improve the situation for girls (i.e. gender stereotypes). Bauer agrees and writes that "a female's inherited position in society is directly related to the mistreatment she receives in school," (Bauer, 1999). Females make up the subordinate culture in our society, while males make up the dominant culture, and schools are doing little to break the cycle (Bauer, 1999; Schwartz \& Hanson, 1992).

Another example of society's impact on students can be seen at lunchroom tables and on playgrounds during recess (M. Sadker \& D. Sadker, 1994; CSP, 2001). Boys and girls take it upon themselves to separate themselves during lunch and recess. Generally, boys look down upon other boys who interact with girls during lunch and recess. This implies that girls are not good lunch partners or good athletes (CSP, 2001). College classrooms may not be much better. Sadker and Sadker (1994) found that one-third of college classrooms are gender-segregated by the students themselves. When teachers or students use "girls" in a derogatory way and direct it toward boys, the implication is still there: boys are better (M. Sadker \& D. Sadker, 1994). Teachers unknowingly create the same implication that girls are not as good as boys when they refer to the whole class as “guys,” (Matthews, Binkley, Crisp \& Gregg, 1998).

Society's role in gender stereotypes also manifests itself within the faculties and administrations in schools. In 1987, eighty-four per cent of the elementary faculties were 
female, and ninety-nine per cent of the superintendents were male. The Council for School Performance feels that this reflects and helps to perpetuate a society in which men dominate and have the power. According to the Council, the only people women have power over in our society are children (CSP, 2001). The disproportionate ratio does not end in high school. There is also an imbalance in faculties at the collegiate level. A majority of males make up most of the college faculties. Female students, therefore, may find it difficult to have female role models, counselors, and mentors, especially if they desire to enter a male dominated field. For example, ninety-eight per cent of the engineering faculties are male (M. Sadker \& D. Sadker, 1994).

Karp and Shakeshaft (1997) feel that the types of teachers schools have as part of their faculties also has an impact on girls and their math achievement. Any students, girls in particular, who have teachers who are teaching out of their certification area or who have a negative view of math can have a negative impact on students' mathematics achievement.

Another possible cause for the gender divide in mathematics, according to some researchers, is the fact that girls do not like math. The NAEP claims that female high school seniors are more likely than male seniors not to take additional math classes because of poor performance in the subject matter. Females are also more likely than males to report being advised against taking upper level math classes their senior year. Thirty-two per cent of the females in the study said they were told that they did not need additional coursework in mathematics, while only twenty-six per cent of males received 
similar advice. The NAEP found that female seniors claim that they did not take math classes, because they did not like the subject matter. Thirty-five per cent of the females in the study claimed this, while only twenty-two per cent of the males identified this as their reason for not taking mathematics classes as seniors. Males identified a different reason. They claimed that they did not need the subject for what they planned on doing in the future (i.e. future employment) (“Girls Math Education,” 1998).

Wiest (2001) also states that high school senior girls are more likely than high school senior boys to say that they did not take mathematics courses because they disliked the subject matter. Wiest also states along with Scwartz and Hanson (1992), however, that senior girls identified the fact that they were advised that they did not need the classes as ano ther reason not to take mathematics courses.

Another reason girls may not continue in math is because they do not see math as an integral part of their lives (Schwartz \& Hanson, 1992; M. Sadker \& D. Sadker, 1994). Math seems to be unconnected to them. As a result, they develop a dislike for math. Schwartz and Hanson (1992) feel this is a detriment, because liking a subject is an important key to doing well in it.

This literature review has already touched on some of the effects a gender gap in mathematics may have on girls such as not taking a full mathematics course track in high school, scoring lower than males on high stakes tests, losing scholarships, limited career 
choices, and lower salaries than males. Researchers have identified other effects that they feel are serious enough to warrant attention.

A recurring theme is the effect that the mathematics gender gap has on girls and their self-esteem and self-confidence. Girls in lower elementary and middle elementary school have a strong self-esteem. Sadker and Sadker (1994) feel that a good self-esteem is directly connected to academic achievement and career goals. A healthy self-esteem, according to Sadker and Sadker, gives girls a hope for the future. Sadker and Sadker (1994) feel that a gap in self-esteem separates boys and girls as they enter adolescence, about the same time the mathematics gender gap begins. Not only does the mathematics gender gap increase with age but also the division about how students feel about themselves (M. Sadker \& D. Sadker, 1994). Even though girls perform better in school, they maintain a lower self-esteem and a lower confidence level than boys (Sanders, 1997).

As girls' confidence levels drop, so do their achievement levels. A lack of selfconfidence may cause girls to abandon mathematics altogether (Tschumy, 1995). The Council for School Performance reviewed a 1989 study done by Coley on the confidence levels of boys and girls in math. The students were to respond to the statement, "I am good with numbers." At each of the three grade levels studied (third, seventh, and eleventh) more boys said they were good with numbers than did girls. The difference in the positive responses between boys and girls increased with age (CSP, 2001). In a study done by Wigfield (1997), it was concluded that elementary boys' beliefs of their 
competence in mathematics was stronger than elementary girls' beliefs in their competence in mathematics. Wigfield also found that this did not change over a three year period (Tiedemann, 2000).

Karp and Shakeshaft (1997) say that there is a strong correlation between a student's confidence in math and his or her math achievement. Males typically exhibit greater confidence in their abilities to learn math than girls. A student's level of confidence in mathematics tends to be a good predictor of whether or not students will continue in optional higher level math classes.

Tschumy (1995) also writes that males, as they make the transition from elementary school to adolescence, increase their confidence levels in mathematics, while females experience a drop in their confidence. When girls' self-esteem drop, their achievement suffers too. Many times when girls' confidence levels drop, they abandon math altogether (Tschumy, 1995). The Women's Freedom Network (1997) does not wholly agree. They claim that boys do have higher self-esteem scores but only by four to six percentage points which, in their opinion, is not enough to suggest the difference is damaging to girls.

Sadker and Sadker (1994) have researched this topic and have made the connection between self-esteem and academic achievement, especially in math. Girls and boys who do well in these subjects consider themselves to be more important, like themselves more, and feel better about schoolwork and family relationships. They are 
also more likely to aim toward professional careers. In their study of elementary girls, they found that thirty-one per cent of the girls say they are good at math. In middle school, only eighteen per cent claim that they are capable of doing math. The cycle begins. When girls lose the confidence to do math, they avoid the subject. When they avoid the subject and have fewer experiences in it, they become less capable. When they become less capable, their self-esteem decreases, and the cycle continues. Sadker and Sadker write, "When girls stay away from academic success, they give up the very thing that leads them to have a high self-esteem,” (M. Sadker \& D. Sadker, 1994).

There may be a link between how boys and girls view their successes and failures and their levels of confidence. Boys generally believe their failures are due to a lack of effort while their successes are due to their own talents and skill. Girls, on the other hand, believe that their failures are due to a lack of ability and their successes are due to outside forces such as, "The teacher likes me," (M. Sadker \& D. Sadker, 1994; Tschumy, 1995). With the male approach, internalizing success and externalizing failure, males are able to tackle new and challenging tasks which allow them to develop the ability to face difficulties and prepare them for future achievement. The female approach of attributing success to effort and failure to lack of ability, teaches females learned helplessness. They do not persist when confronted with difficult academic material or content, and they often give up (M. Sadker \& D. Sadker, 1994).

Karp and Shakeshaft (1997) also identify how males and females view their standardized scores as a possible link to levels of confidence. Females are more apt to 
accept scores from standardized tests and high stakes tests such as the SAT as an accurate measure of their intelligence. Females do not score as high on the mathematics sections of these tests; therefore, they think they are not as smart in mathematics as they previously thought. As a result, they begin to lack the confidence needed to apply to colleges that request higher SAT scores. Sadker and Sadker (1994) agree that girls reject the validity of grades, which are likely to be higher, and believe the test scores, which are likely to be lower, as a true measure of their intelligence.

A lack of confidence manifests itself in many ways such as course avoidance, choosing traditional female collegiate courses and careers, or not applying to college at all. Another way a lower confidence level manifests itself is how females conduct themselves in the classroom. Sadker and Sadker (1994) feel the silence females exhibit in the classroom is directly related to the lack of confidence they feel. As girls grow older, they grow more and more quiet in the classroom and are less likely to participate in classroom discussions. Female silence becomes the norm.

A study done by Sadker and Sadker (1994), documents the silence of girls from grade school through graduate school. The study concluded that forty-eight per cent of boys and thirty-nine per cent of girls speak up in class. Twenty-eight per cent of boys and fifteen per cent of girls said they argued with teachers when they thought they were right. The AAUW conducted a similar survey and also found that girls are more quiet and hidden in the classroom (M. Sadker \& D. Sadker, 1994). 
Sadker and Sadker (1994) go on to write that eighty per cent of elementary and secondary pupils contribute at least one comment per class. Approximately half of a college class, however, says nothing at all. One in two sits through an entire college class without ever making a comment, asking a question, or even answering one. According to Sadker and Sadker, twice as many college females are silent as college males. Men are also twice as likely to dominate or monopolize a class discussion than females. Women are twice as likely to be silent. Sadker and Sadker summarize female silence as "Males perform. Females watch," (M. Sadker \& D. Sadker, 1994).

As the confidence levels of girls continue to drop over time, many are faced with the decision of dropping out of school altogether. Many researchers claim that there are more boys who drop out of high school than girls (M. Sadker \& D. Sadker, 1994; The Women's Freedom Network, 1997; D. Sadker, 1999; AAUW, 1999). Between October 1995 and October 1996 boys accounted for fifty-eight per cent of United States drop outs (D. Sadker, 1999). The Women's Freedom Network (1997) also makes the claim that boys are also more likely to repeat a grade than girls.

However, David Sadker, Myra Sadker, and the AAUW claim that girls who repeat a grade are more likely to drop out than boys who repeat a grade (M. Sadker \& D. Sadker, 1994; D. Sadker, 1999; AAUW, 1999). According to the United States Department of Education (1995), ten per cent of males and females who never repeated a grade will eventually drop out. Twenty-two per cent of males and twenty-eight per cent of females who have repeated a grade will eventually drop out (AAUW, 1999). When 
girls drop out, they are less likely than boys to return and finish their schooling (M.

Sadker \& D. Sadker, 1994; D. Sadker, 1999; AAUW, 1999). By age twenty-five, more males than females have earned their high school degrees. When girls drop out, they stay out and are not likely to return (M. Sadker \& D. Sadker, 1994). In 1995, females made up forty-five per cent of the fifteen to twenty-four year olds who dropped out of school that year and fifty per cent of the sixteen to twenty-four year olds who stayed out (M. Sadker \& D. Sadker, 1994).

In order to combat a mathematics gender divide, its possible causes, and its various effects, many things can be done by parents, educators, and administrators alike. Some of the suggestions made by researchers are simple and easy to implement. Others require a possible revamping of course structure and instruction. One main tenet of change is an improvement in the way teachers conduct their classrooms

One way teachers can help students in their classrooms is to eliminate speed and to give students more wait time. Males are "inclined to trust intuitive thinking and holistic examinations of problems," (Karp \& Shakeshaft, 1997) and are, therefore, more likely to give quick responses. Girls, on the other hand, usually revert to "lengthy but reliable formulas," (Karp \& Shakeshaft, 1997). In a study conducted in Kentucky, it was found that there were more males on quick recall academic teams and more females on problem solving teams that use creativity and cooperation. By using more wait time and using less timed work, females have a chance to work through their problems and 
participate more in mathematics (Tschumy, 1995; AAUW, 1996; Karp \& Shakeshaft, 1997; Bauer, 1999).

Teachers also need to make sure that their classroom instruction is balanced.

When a teacher chooses to praise a student, he or she needs to give constructive feedback to both boys and girls, instead of simply rewarding girls' neat work or compliant behavior (Tschumy, 1995). Teachers should provide equal opportunities for boys and girls while respecting their differences. Levi (1995) feels that this does not necessarily mean that teachers should force students to do certain activities like forcing girls to play ball. Levi does feel, however, as does the AAUW (1996), that teachers should make it clear that they value each activity and interest equally. Teachers also need to make sure that both boys and girls have the same experiences in math such as giving them equal praise and calling on them equally (Levi 1995; Bauer, 1999).

Teachers may have to change their teaching methods in order to meet the needs of girls and in order to meet their mathematics needs. Teachers need to make sure that girls see the relevance of math to their lives. Girls need to see how math fits into their lives and need to see that math is meaningful (Schwartz \& Hanson, 1992; Karp \& Shakeshaft, 1997; Wiest, 2001). Teachers need to display a positive attitude in math related activities in order to keep students interested in math and help them to see its importance ("Girls Math Education," 1998). 
Teachers also have the responsibility to help children understand their attributions of their successes and failures. Girls need to learn that their successes are indeed due to their ability, knowledge, and effort and not simply to luck or other outside factors (Bauer, 1999). Teachers also have the responsibility to send positive messages to students in order to build their confidence levels (Bauer, 1999). Teachers need to be careful that they do not send negative messages by calling students "guys" or telling their boys to “stop acting like a girl,” (Tschumy, 1995).

Many researchers feel that using cooperative learning structures in mathematics classes can dramatically improve girls' confidence levels. Research shows that females respond more favorably to cooperative learning groups than to competitive ones (Schwartz \& Hanson, 1992; Tschumy, 1995; Karp \& Shakeshaft, 1997; Bauer, 1999).

Administrators also have a responsibility in ensuring an equal mathematics education for both boys and girls. Karp and Shakeshaft (1997) write that one aid administrators can offer girls and teachers is to hire mathematics specialists from elementary through high school. These specialists could model mathematics lessons for teachers, could suggest more challenging topics, could demonstrate how to use hands-on materials at all levels of mathematics instruction, and could display an overall positive attitude about math. Another way administrators can become involved in solving the mathematics gender divide is to supervise instruction themselves. Administrators should be available to teachers to encourage them to use hands-on activities, help them to use real-life settings in mathematics, to avoid speed, and to help them identify subtle 
differences they may have in dealing with the boys and girls in their classrooms (Karp \& Shakeshaft, 1997).

Another responsibility administrators have, according to Karp and Shakeshaft (1997), is to identify "female flight". This involves identifying female students who are at risk of abandoning mathematics and associated careers. Administrators can accomplish this by looking at students' grades, listening to casual comments made by students, using attitude scales, and observing classroom performance and participation. Administrators can also identify female students who have the ability to perform higher levels of math but continually choose lower level classes (Karp \& Shakeshaft, 1997). They may even desire the aid of the guidance counselor in identifying and stopping female flight. Guidance counselors can also help girls stay in the mathematics track by being a support system for them. For example, a school district in Long Island, New York does not allow females to drop out of the mathematics sequence unless they meet with the guidance counselor. The guidance counselor discusses the dangers of not completing a mathematics track such as damage to being accepted into college, or more prestigious colleges, and the possibility of not meeting their future goals (Karp \& Shakeshaft, 1997).

Teachers and administrators should work together in order to provide girls with positive role models in the realm of mathematics. Many women presently in the mathematics field say that they had female role models as younger students. They explain that their schools had developed summer and after school programs for girls who 
were interested in math (Schwartz \& Hanson, 1992; Karp \& Shakeshaft, 1997). These programs could very easily help to reduce the feeling of isolation that girls who are interested in nontraditional fields often express (Karp \& Shakeshaft, 1997). Another way to include positive role models for girls is to have guest speakers who are involved in nontraditional roles speak to students (AAUW, 1996).

Many researchers feel that administrators need to provide their teachers with more education in the area of gender inequities in mathematics and how to combat them. There needs to be an increased awareness among faculty personnel of the problems of gender inequities (Levi, 2000). This can be done in a number of different ways.

Administrators could begin discussions through the use of questionnaires amongst their faculty (Levi, 2000). This can also be done through actual courses that teacher education students would be required to take. There is presently very little instruction given to teacher education students or to current teachers in this area. Sanders (1997) identifies various studies that have been done in the area of educating teachers about a gender divide in mathematics. The Teacher Education Equity Project which was founded by the National Science Foundation (NSF), IBM, Hewlett Packard, and AT\&T, taught college professors how to teach about gender equity. This study was conducted in forty colleges and universities in twenty-eight states. The evaluation of the study showed that eightyfive per cent of the professors involved in the study made significant improvements in their own gender equity teaching behavior. 
Another project, Integrating Gender Equity and Reform, funded by the Georgia Institute of Technology and NSF, provided materials and methods for teaching gender equity to pre-service teachers. The Teacher Education Mentor Project, also funded by NSF, provided gender equity instruction in mathematics teacher education programs. The U.S. Department of Education's Gender Equity Expert Panel (1996) designed and began a process for "identifying, reviewing, and recommending promising and exemplary programs, products, and practices to educators and community members" that would encourage gender equity in mathematics (Sanders, 1997). Sanders (1997) feels that colleges and universities need to create and implement gender equity courses as part of their teacher education programs.

Parents also have a great impact upon their child's mathematics performance. Tschumy (1995) feels that parents need to begin with having high academic expectations for their girls. When a mother says, "Ask your dad for help. I was no good in math," it sends a negative message to girls that females cannot excel in math but males can. Tschumy (1995) suggests that mothers say something that will encourage girls to persevere in math such as, "I wasn't confident enough to study math the way you do. I'm proud of you." Karp and Shakeshaft (1997) agree that parents need to be educated. Parents of boys have more positive beliefs about their sons' math abilities and performance and desire their sons to continue in mathematics courses than parents of girls do. According to Karp and Shakeshaft (1997), the parents of girls rated their daughters' abilities in language arts higher than in math, even though girls received the same grades. Conversely, boys' abilities were rated higher in mathematics than language 
arts when they received the same grades in both subjects. Parents need to be taught that girls have the ability to excel in mathematics, too.

Another way parents can encourage their girls to excel in math is to encourage them to become involved in sports. Being involved in an athletics program teaches boys and girls to learn how to take risks and how to lose along with how to win (Tschumy, 1995). Physical activity leads to higher self-esteem and self-confidence which carries over to the classroom (Sadker, 1999). Sports also builds stamina, courage, leadership, and loyalty to team while building up self-confidence and the drive to win, (Sadker \& Sadker, 1994).

One suggestion in particular, single-gender mathematics classes, has ignited much debate. The author has chosen to study single-gender mathematics classes as a possible solution to the mathematics gender divide. Single-gender mathematics classes and the results of the author's study will be discussed in further detail in chapter three.

Out of the twenty-four sources discussing the gender gap in mathematics, twentyone of them agreed that there was some type of divide with boys excelling in math over girls. These twenty-one sources also provided suggestions as to how to combat gender inequities in mathematics. The author is confident that she has exhausted the research made available to her and has cited this research throughout her literature review and again in her reference list. The author readily admits that there may be additional studies not available to her on the topic of a gender divide in mathematics. The author also uses 
seven additional sources devoted directly to single-gender mathematics classes in chapter three. There are also citations throughout chapter three and in the author's reference list. 


\section{CHAPTER III: Procedures and Results}

\section{Presentation of the Problem}

There is much debate as to the value and possible benefits of single-gender education amongst researchers today. Many claim its benefits and adhere to the positive gains made in girls' self-esteem levels and interest in mathematics classes. Opponents to single-gender education cry that it is in direct violation of Title IX and that there has been no research to document achievement gains for girls in single-gender schools or classes. In this chapter the author attempts to look at both sides of the research concerning singlegender education. The author then will discuss her research findings based on her experiences of teaching a single-gender mathematics class.

Most of the research that has been conducted concerning single-gender mathematics classes has taken place in the private sector or internationally (Streitmatter, 1999). Presently, eleven percent of the private schools in America are girls-only schools while eight per cent of the private schools are boys-only schools. In the United States, Title IX of 1972 was designed to abolish sex discrimination in public schools (Sadker \& Sadker, 1994). Title IX reads, “A recipient shall not provide any course or otherwise carry out any of its education programs or activity separately on the basis of sex," (Streitmatter, 1999). Therefore, it is illegal to have single-gender public schools or even single-gender classes (Sadker \& Sadker, 1994). Private schools, however, are not held to Title IX. Private schools may choose not to receive government funding, and, therefore, do not have to uphold Title IX, which explains why most research of single-gender 
schools has taken place in the private realm. Some public schools have attempted to "work around" Title IX. These schools will be discussed later in this chapter.

Title IX does make some allowances for separate-sex classes in public institutions. If a course offered in the public school involves physical contact such as in physical education classes or discusses human sexuality in any way, single-gender classes are permissible. It also allows for remedial and affirmative action. Title IX defines remedial action as "if a recipient has discriminated against a person on the basis of sex in an educational program or activity, such recipient shall take such remedial action as the Assistant Secretary deems necessary to overcome the effects of discrimination.” Title IX goes on to define affirmative action as "a recipient may take affirmative action to overcome the effects of conditions that resulted in limited participation of a particular sex," (AAUW, 2002). These allowances, for some, open the door to separate-gender schools or single-gender classes in the realm of public schools.

There is a separate debate concerning a possible revision of Title IX. It is not the purpose of this paper to debate the issue, however, the researcher feels it necessary to outline the debate surrounding Title IX as it relates to single-gender instruction. Some feel that a revision is necessary in order to allow for school choice. A revision would allow all students to have a choice to attend a single-gender school and not simply those who can financially afford a private school tuition (Sadker \& Sadker, 1994). Others say that Title IX should stay as it is. Opponents to a revision of Title IX, such as civil rights activists and feminist groups such as the National Organization of Women (NOW), 
remember how women were once discriminated against in the past and feel that Title IX serves as the protection that they need to guarantee equality in education (Sadker $\&$ Sadker, 1994; Stainburn, 2000).

Many researchers feel that single-gender schools and instruction are good for girls and their education (Sadker \& Sadker, 1994; Tschumy, 1995; AAUW, 1996). In singlegender schools girls' self-esteem increases, they become more interested in nontraditional subjects like mathematics, they are less likely to stereotype jobs and careers, and they become more intellectually curious and serious about their studies. Together these cause them to achieve more than girls in coeducational institutions (Sadker \& Sadker 1994).

Single-gender colleges offer similar benefits, too. Women attending singlegender colleges have a higher self-esteem and higher academic and career achievements than those attending coeducational colleges and universities. Those graduating from women's colleges receive more degrees in nontraditional fields like mathematics and are between two and three times more likely to enter medical schools than are their coeducational partners. They are also better represented in Fortune 500 companies and at the highest levels of government (Sadker \& Sadker, 1994). Smith (1990) found that women in single-sex colleges were more satisfied with their schooling, their contact with faculty and administration and the overall quality of instruction than women in coeducational colleges (Streitmatter, 1999). 
According to Sadker and Sadker (1994) a possible reason for this apparent success is the availability of female role models in all-girls' schools that are often not readily available in coeducational schools. For example, fifty per cent of the science and math faculty at women's colleges are female compared to only twelve per cent at coeducational institutions. Another reason for the success girls achieve in single-gender schools may be due to the fact that girls are actively involved in the learning process and not merely spectators as is often the case in coeducational programs.

Sadker and Sadker (1994) visited highly selective girls' schools and spent time observing classes and conducting interviews with both students and teachers. They found that the girls attending these schools were more assertive in asking questions, were not afraid to openly admit when they did not understand something or were confused, and did not worry about things like popularity or being embarrassed. A few students did voice their concerns about not being given the opportunities of learning how to deal with boys. The teachers who had previously taught in coeducational schools readily admitted that they preferred teaching in an all-girls school. Some of the teachers commented that boys are too demanding of a teacher's attention or are verbally aggressive. In a coeducational setting the teachers felt that they had to first develop a personal relationship with the girls before the girls began taking risks. It was different in the all-girls schools, however. According to the teachers, the girls take more chances in an all-female setting.

Stainburn (2000) points to a success story in Philadelphia. She examines one of three public all-girls schools that are currently open in the United States. (The other two 
are located in Baltimore and New York City. There are two more under way in Denver and Chicago.) The Philadelphia High School for Girls offers a large selection of Advanced Placement courses, has a ninety-eight per cent college acceptance rate, and has an award-winning robotics team. The teachers report that "the absence of boys, "the biggest distraction for teenage girls,' enabled them to teach more advanced classes more effectively."

Over the past nine years, enrollment at the Philadelphia High School for Girls has increased. In 1991, 1,100 girls were enrolled. In 2000, the enrollment jumped to 1,480. The enrollment reflects a diversity in race and ethnic background as well as socioeconomic background. Some of the students come from very poor backgrounds. According to the principal of the school, Geraldine Myles, some of the reasons for the increased enrollment include promoting a higher self-esteem in girls, the high academic standards that the school holds, leadership opportunities for the girls enrolled, and the safety that can be found at the school (Stainburn, 2000).

The Philadelphia High School for Girls avoids Title IX by simply keeping quiet on the subject of gender. The school has no written policy to keep out boys. They simply attempt to meet the needs of the boys who come their way by pointing them in other directions. For example, they point boys to schools close in proximity to Philadelphia High School for Girls that offer the same college preparatory classes as they do (Stainburn, 2000). 
Archer (1998) also examines two private schools that have a coeducational enrollment but offer single-gender classes. The Walker School in Marietta, Georgia is a school that begins with a pre-kindergarten class and continues through the twelfth grade. They have 841 students enrolled. The student body is made up of approximately fifty per cent boys and fifty per cent girls. They offer single-gender math and science classes starting in middle school. According to Archer, they separated these classes in order to boost the girls' self-confidence, so girls would not "shut off future options." The administration at the Walker School admits that the girls' performance in the gender separate classes has not changed noticeably. What has improved, however, is the number of girls who are enrolling in upper-level math and science classes. The number has dramatically increased. Before separate instruction was offered, approximately one-third of the students enrolled in upper-level math and science classes were female. Currently, with the separate-gender instruction, girls' enrollment has climbed to between forty-five and fifty- five per cent.

The Marin Academy has also tried single-gender math and science classes in the ninth and tenth grades. They attempted these types of classes for five years but had to stop due to the lack of enrollment by the girls. However, the teachers felt is was still a positive experience, even if the classes ended up being temporary. Because of their experiences of teaching in a single-gender classroom, the teachers felt that they learned what works best for girls and what works best for boys. They have taken what they have learned and applied it to the coeducational classroom (Archer, 1998). 
The Illinois Math and Science Academy (IMSA) had a similar experience after teaching one semester of a single-gender physics class. IMSA is a public, state-funded high school for talented mathematics and science students. They conducted a study in order to determine if a girls-only section of an advanced physics class would allow the girls to gain greater self-confidence, participate more, and demonstrate higher achievement. The teacher also incorporated more hands-on activities that showed the students the relation physics has to real life (Streitmatter, 1999).

The result was that the girls section did display greater growth in anaylsis and problem solving (Streitmatter, 1999). Even tho ugh the class was only offered one semester, the teachers felt it was beneficial to them. Like the teachers from the Marin Academy, they learned what works best for both genders. The teachers involved in this change, even for one semester, also made a change in their teaching styles upon returning to a coeducational classroom (Archer, 1998).

Another success story can be found in the Women's Leadership School in East Harlem, New York. At the Women's Leadership School, they have near perfect attendance, their girls experience an increase in self-esteem, and the reading scores of the girls enrolled average approximately twenty points higher than the coeducational schools in the same district (Walleser, 1998).

There are many voices to support single-gender programs. Meg Moulton, coexecutive director of the National Coalition of Girls' Schools, says that single-gender 
learning gives girls a "big academic boost" in math, science, and technology (Stainburn, 2000). Eileen Lambert from the Rippowam Ciqua School in Bedford, New York says "It's enough knowing I have more girls saying 'I love math,"” (Archer, 1998). Despite the success stories, there has been no conclusive evidence that proves single-gender programs result in higher academic performance for girls when comparing them to girls in coeducational institutions (Smith, 1996; Sanders \& Peterson, 1999; AAUW, 2000; Haag, 2000; AAUW, 2002).

In a study conducted in Australia by Rowe (1998), it was determined that there was no statistical significant difference in achievement in math based on the types of classes in which the girls enrolled (either coeducational or single-gender). However, the girls did increase their confidence in their mathematics abilities which increased the likelihood that they would take higher level mathematics classes later in their academic careers (Smith, 1996).

In a similar study conducted in Sydney over a five year period, Smith (1996) followed students who began their schooling in single-gender schools and moved into coeducational schools. Smith found there to be no change in the math achievement of the students involved in the study. The boys continued to do slightly better in math than the girls.

According to the AAUW there are many dangers involved in single-gender schooling and instruction. They claim that single-gender programs reinforce men and 
women stereotypes and roles in society just like in coeducational programs (Walleser, 1998; AAUW, 2000). Lee, Mark, and Byrd (1994) also found that the teachers "talked down" to the girls in single-gender situations, would reinforce hard work rather than correct work, and created more of a dependency of the girls on their teachers than the teachers in an all-boys school or in a coeducational setting (Streitmatter, 1999).

Datnow, Hubbard, and Woody (2001) came to similar conclusions. They examined a California experiment in which six public single-gender schools were established. They were involved in a three year case study in which they conducted more than 300 interviews with educators, policymakers, and students and conducted extensive school and classroom observations. The schools ranged from grades five through twelve, depending upon the location of the school. The study was conducted between 19982000. Most of the schools involved in the study served low-income students, and the members of the schools were mostly from racial/ethnic minority groups.

Their findings also claim that traditional stereotypes were still reinforced, despite the gender separation. Boys were still taught in regimented, traditional, and individualistic styles. The girls were taught in a more nurturing, cooperative, and open environment. Students were taught this way based due to the perceptions the teachers had based on the gender of their students. Teachers viewed boys as being talkative and active, so they were taught in a more traditional way which allowed the teacher to have more control in the classroom. The teachers viewed the girls as studious, cooperative, 
and well-behaved, so they were taught in a different way than the boys (Datnow, Hubbard \& Woody, 2001).

According to Datnow, Hubbard, and Woody (2001), students also often received mixed messages about gender from their teachers causing gender stereotypes to be reinforced. Girls were taught that they had big choices in life but were at the same time encouraged to be feminine and to be concerned about their appearance. Boys, on the other hand, were told it was permissible to cry, but they also had to be strong and take care of their wives.

Many debate the apparent higher self-esteem in girls in single-gender schools. Some feel that it may not be because of the single-gender programs in and of themselves (Walleser 1998; AAUW, 2000; Haag, 2000; AAUW, 2002). It could be due to the fact that the girls in these schools are receiving a good education (AAUW, 2000). The AAUW holds to the idea that if a good education is present, both boys and girls will succeed (Walleser, 1998; AAUW, 2000; AAUW, 2002).

According to the AAUW (Walleser, 1998; AAUW 2002), a good education involves a number of factors:
- small classes
- rigorous curriculum
- high standards
- discipline
- good teachers
- attention to eliminating gender bias 
A good education also requires establishing an equitable learning environment (Walleser, 1998; AAUW, 2002). This includes making sure that all students learn. Administrators would also be required to initiate staff development in gender-fair teaching methods and recruit and make female and minority administrators visible. Administrators would also have to make sure that nondiscrimination policies are in place as well as sexual harassment policies and prevention programs along with equitable athletic programs.

The AAUW readily admits that the long-term impact of single-gender schooling is unknown and that more research is needed (AAUW, 2002). However, they feel that the research that is learned from single-gender programs should be used to make coeducational institutions better for all students and not simply reinforce single-gender education (Walleser, 1998; AAUW, 2002).

Sanders and Peterson (1999) offer similar solutions within coeducational settings. They suggest an in-depth staff development program instead of single-gender programs. Sanders and Peterson feel that it is important that there be a continuous dialogue between teachers, parents, and students about the roles of professional women in the future. The administration must lead and support teachers as they use gender equity training, work with counselors to keep girls in mathematics programs throughout high school, and provide girls with appropriate female role models. Administrators and teachers alike should be actively involved in educating parents how to encourage their daughters to pursue mathematics courses and careers. Administrators and teachers could also develop 
programs to teach young girls about the many career opportunities available for young people with a strong math background. Sanders and Peterson feel, as does the AAUW (2002), that single-gender programs are not the answer for our girls, but improving coeducational institutions is the key to success for all students---boys and girls alike.

Lee (1997) has come to similar conclusions. She writes, "In general, separating the secondary educational experience by gender, either in separate classrooms or separate schools, is not an appropriate solution to the problem of gender equity in educational settings, in either the short or the long run. Although separate-by-gender education may benefit particular students (usually girls), or be beneficial to some in particular settings (perhaps in Catholic schools), the research basis for the benefits of single-gender education as a policy change is not solid."

Instead, Lee (1997) also encourages the development of "good" schools. Good schools include having smaller schools with a more academic orientation while encouraging less parental involvement. According to Lee, schools with higher parental involvement have higher gender gaps in mathematics, favoring boys. Lee goes on to say that good schools have a core curriculum, are more communities rather than bureaucracies, and use constructivist teaching methods within their classrooms. This type of instruction would be seen in every classroom and not used in isolation (i.e. some teachers teach using constructivist principles while others do not). Finally, according to Lee, good schools are full of teachers who believe all their students can learn, believe in 
their own ability to teach all their students, and are willing to take on the responsibility for the students' learning.

Lee (1997) concludes that segregated schools or even segregated classes are not good. This type of instructional program may not disadvantage girls but does disadvantage boys. According to Lee, even separate mathematics classes are a misguided approach to the problem. Lee feels that when single-gender classes are implemented, the girls receive a watered down approach to the material. The material is made easier which causes a move from a more rigorous academic experience, as if the girls could not handle the more difficult material. Instead, schools should work on the necessary adaptations needed to build good schools that would benefit all students.

After reviewing some of the research available to the author, the author was curious as to how her students would respond to a single-gender math program. The author was hoping to learn what would best meet the needs of her students but especially the needs of her female students in the area of math. The remaining sections of this chapter discuss the subjects, the method, and the outcomes of the author's research. The author conducted her research at Calvary Christian School in Covington, Kentucky in her fifth grade classroom. 


\section{Presentation of the Hypotheses}

In order to determine if single-gender classes would benefit her female students and their achievement in math, the author conducted a study in order to test the following hypothesis:

$\mathrm{H}_{0}$ : There will be no significant difference in the girls' scores when comparing the girls' scores received in a coeducational math class with the girls' scores received in a single-gender math class.

The researcher also wishes to determine if the girls believed the separation helped them to learn math better. The following hypothesis was used to determine if a change in attitude occurred:

$\mathrm{H}_{0}$ : There will be no statistical difference in girls' perceptions of how they best learn math when comparing perceptions in a coeducational setting and perceptions in a single-gender setting.

\section{Subjects}

Calvary Christian School contains two classes per grade. The author is one of the fifth grade teachers there. Her teaching partner agreed to take part in the study. All the students participated in the study. There were a total of fifty students: twenty-five male students and twenty- five female students. All were from a middle to upper socioeconomic class. Ninety-eight per cent of the students were Caucasian. Their ages ranged from ten to eleven at the time of the study. The author divided the class based on gender. The author taught the male students for seven weeks throughout March and April. The author's teaching partner taught the female students over the same time period. 
The parents of the students were notified concerning the study (see Appendix A for a copy of the parent correspondence). Initially, there was no negative feedback concerning the separate math classes. Any parents who contacted the author were excited that their child could participate in the study. Approximately halfway through the study, a few parents of some of the author's female students, voiced concern over the drop in their children's grades. These parents were anxious for the study to conclude and for the female students to return to the researcher's classroom for math once again.

\section{Variables}

\section{Independent Variables}

The independent variable is the single-gender classroom environment. Students were separated into two classes based on their gender. The author taught three math chapters to the male students $(n=25)$, and the author's teaching partner taught the same three math chapters to the female students $(n=25)$. The author desired to see if a singlegender math class has an effect on female's math achievement and/or attitude toward mathematics. The same independent variables existed for both hypotheses.

\section{Dependent Variables}

The two variables that were measured were the achievement levels of the females and the perceptions of the females towards learning math. For the first hypothesis, the females' achievement levels, which were measured based on average math grades, was the dependent variable. The average math grade was computed by averaging the last three chapter test grades prior to the separation. These averages were then compared 
with the averages of the three chapter test grades received during separate-gender instruction. The averages were compared in order to determine if an increase had occurred for the females while in single-gender instruction.

In the second hypothesis, the dependent variable was the perceptions of the females as to how they best learn math. The students were given a survey to complete prior to the initiation of separate math instruction. A sample question is, "How do I rate myself in math?" with the choices of "poor, OK, good, wonderful." (For the complete survey, please see Appendix B). The same survey was then given upon the completion of the single-gender instruction study with one additional question, "Did separating the classes help you to learn math better? Why or why not?" (For a complete survey, please see Appendix C). The surveys were then compared in order to determine if a change in attitude toward math had occurred for the females and if they felt separating the math classes helped them to learn math.

\section{Procedures}

Students were first notified of the study at the beginning of March. They were told that as part of the author's graduation requirements, she had to conduct some research, and they were going to get to help. The author also explained that she could not

go into much detail about her study, so the results were not affected. She did explain that for six weeks (which turned into seven) math class would be different. The girls would go with Mrs. Heyob (the other fifth grade teacher), and the boys would stay with the 
author. The author's impression of the students' first reactions was that the boys were very excited about the separation, but the girls were not.

A letter informing the parents was then sent home, upon approval of the author's principal. As previously mentioned, parents were very supportive of the author and her research. As time went on, however, they became anxious for "things to get back to normal." A survey was then given to the students prior to the separation of classes. It was given to all the subjects and kept anonymous.

The study was conducted over a seven week period starting in mid-March, 2002 and completing at the end of April, 2002. Both teachers of each gender classroom taught the same lessons the same days. The teaching methods did not vary. Both teachers also assigned the same homework to be completed independently. The teachers made every effort possible to make sure the subjects were receiving identical instruction. (For sample lesson plans, please see Appendices D-G).

The first chapter taught in the single-gender environment was the addition and subtraction of fractions. This included fractions, mixed numbers, and putting fractions in lowest terms. The second chapter included instruction on multiplying and dividing fractions. For multiplication, it included fractions and mixed numbers. For division, the subjects were only taught how to divide fractions. Dividing fractions using mixed numbers was not taught. Putting fractions into lowest terms was also part of the instruction. The third and final chapter that was covered was geometry. This included 
basic definitions of terms such as line, segment, ray, and point. It also included identifying polygons and symmetrical figures and objects. Tests were given upon the completion of each chapter. The tests varied in format. Students were required to solve problems, solve problems using a multiple choice format, match vocabulary terms to their correct definitions, and recognize and identify various geometric figures. Upon completion of the final unit in geometry, a second survey was given in order to determine if any changes had occurred in the girls' perceptions concerning math.

\section{Results}

Prior to the division of the classes based upon gender, each of the fifty fifth graders was given a survey to complete (see Appendix B). The author used this survey to determine the attitudes of the female students who had been, up to this point in the academic year, participating in a coeducational math class. Students were asked simply to identify themselves by their gender (i.e. mark whether they were a boy or girl). All papers remained anonymous.

In the first question, students were asked to identify their favorite subject. Forty per cent of the girls in fifth grade chose the language arts (reading, English, or spelling) as their favorite subject. Twenty-eight per cent chose math as their favorite subject. The remaining thirty-two per cent chose either science (eight per cent) or history (twenty-four per cent). For a summary of the findings of the survey see Table 1. 
Students were then asked to predict if they would go to college and what the ir future careers may be. Of the females asked, ninety-two per cent said they planned on going to college. Only eight per cent said they did not see themselves going to college. When asked what they imagined they would be when they grew up, sixty-eight per cent of the girls chose traditional female careers. This included being an author, teacher, nurse, or actress. Thirty-two per cent chose non-traditional female careers such as doctors or scientists.

Even though only twenty-eight per cent of the females surveyed chose math as their favorite subject, fifty-two percent said they did like math compared with forty-eight per cent who said they did not like math. Some of the reasons the girls claimed they liked math was because it was important (related to future employment) (eight per cent), it was challenging (twelve per cent), or it was easy and fun (thirty-two per cent). Those who did not like math gave two main reasons why: it is difficult (they were not good at it) (thirty-two per cent), or it was boring (sixteen per cent).

The final question on the survey asked students to identify how they would describe themselves in math. They were to rate themselves using the terms, "poor," "OK" (which was orally defined as average), "good," or "wonderful" (which was orally defined as it comes easily to you). Eighty-four per cent of the females chose the middle ranking of either "OK" or "good" with most of them choosing "good" (sixty per cent chose "good" and twenty-four per cent chose "OK"). Only twelve per cent said that they 
were "wonderful" in math and felt that it came easily to them. Four per cent felt that they were "poor" in math.

After the treatment was completed seven weeks later, a second survey was given to the students (see Appendix C). The results did not show much change in female opinions at the conclusion of the seven weeks in a single-gender mathematics class. See Table 1 for a summary of the findings.

There was an increase in the number of students who identified math as their favorite subject in the second survey. Prior to the single-gender math class, twenty-eight per cent of females said that math was their favorite subject. After the single-gender math class, thirty-six per cent of the females surveyed identified math as their favorite subject. Thirty-six per cent chose language arts (down from the forty per cent who chose language arts in the first survey). Twenty-four per cent chose heritage and four per cent had no response.

When asked if they saw themselves attending college, eighty per cent said "yes" while twelve per cent said "no." Four per cent had no response. Despite the increase of math as a favorite subject, more females chose traditional careers in the second survey than in the first survey. When asked what they saw themselves growing up to be, seventy-two per cent chose a traditionally female occupation (sixty-eight per cent chose traditionally female careers in the first survey). Four per cent did not respond to the 
question. Twenty per cent, down from thirty-two per cent, chose a non-traditional career as a possible future occupation.

There was really no change in the females' opinions about math. In both the first and second survey, fifty-two per cent said they did like math In the second survey, forty-four per cent said they did not like math, because it was too hard, they were not good at it, or it was boring. Four per cent chose not to respond to the question, "Do you like math? Why or why not?"

In the first survey, twelve per cent gave themselves the highest rating when asked to describe their abilities in math. There was no change in the second survey: twelve per cent identified themselves as being really good in math. No one chose the lowest level ("poor") in the second survey. The remaining eighty-eight per cent identified themselves as being "pretty good" or "OK" in math. This is up from eighty-four per cent in the first survey. 
Table 1

Female Survey Responses Before and After Single-gender Math Class

\begin{tabular}{|c|c|c|c|}
\hline & $\underline{\text { Before }}$ & $\underline{\text { After }}$ & Difference \\
\hline $\begin{array}{l}\text { math as favorite } \\
\text { class }\end{array}$ & 28 & 36 & +8 \\
\hline $\begin{array}{l}\text { chose traditional } \\
\text { careers }\end{array}$ & 68 & 68 & 0 \\
\hline $\begin{array}{l}\text { chose non-traditional } \\
\text { careers }\end{array}$ & 32 & 20 & -12 \\
\hline like math & 52 & 52 & 0 \\
\hline $\begin{array}{l}\text { confident in math } \\
\text { ("wonderful") }\end{array}$ & 12 & 12 & 0 \\
\hline
\end{tabular}

Note: Results given in percentages

The last question found on the second survey was an opinion question, "Did separating the classes help you learn math better? Why or why not?" Six per cent of the girls participating in the single-gender math class said they felt that there was no change. They did not learn any better yet learning was no more difficult in the single-gender setting. Eight per cent said it was harder for them to be in the single-gender classroom, because the girls were distracting to them and prevented them from learning. However, sixty-eight per cent of the females in the single-gender math class said that not having the boys in the room was a benefit to their learning. They listed reasons like it was easier to concentrate without the boys around to distract them (thirty-six per cent), they felt more comfortable without the boys present (twenty per cent), and their grades improved in the single-gender class setting (twelve per cent). 
The researcher ran a Chi-Square test in order to see if a statistical difference was present for the last question. The researcher desired to know if there was a statistical significance in the girls' opinions concerning the benefit to the single-gender classroom. The researcher used SPSS for Windows Student Version Release 6.1.3. The degrees of freedom was 2. The $\chi_{\text {crit }}^{2}=5.99$ at the $\alpha=.05$ level. Therefore, since the $\chi_{\text {obt }}^{2}$ was 14.48 , a statistical significance did exist in the girls' perceptions of how they best learn math. The researcher, as a result, rejected the null hypothesis that there is no difference in the perceptions as to how girls feel they best learn math.

The researcher also used SPSS for Windows Student Version Release 6.1.3 in order to conduct an independent samples t-test to determine if there was a statistical significance between the girls' scores earned in a coeducational setting and those earned in a single-gender setting. The means of the girls' scores were used in order to determine any possible statistical significance. The mean scores of the math tests given in a coeducational setting were 95.27. The mean scores of the math tests given in a singlegender classroom were 96.29. Although this was an increase, it was not statistically significant. The standard deviation in the coeducational setting was 5.3, and in the single-gender setting it was 8.10 . The t-value was -.58 with the degrees of freedom equaling 48. At the $\alpha=.05$, there is no statistical significance; therefore, the researcher accepts the null hypothesis that there is no difference in girls' achievement between scores obtained in coeducational and single-gender mathematics classrooms. 
Despite the fact that there was no significant difference in achievement gains, there are many implications that can be made concerning the author's research. Further study on the impact of single-gender classrooms for elementary students must be conducted. The researcher concludes her study and makes recommendations for future studies in the next chapter. 


\section{CHAPTER IV: Summary and Conclusions}

In conclusion, the author feels that in spite of there being no statistical differences in the girls' achievement levels in her study, there are many implications that can be made concerning her female students and how they learn. The researcher's female students are already aware of a difference in math between themselves and their male classmates. As can be seen in the survey, they feel that boys are better in math, math comes more easily to the boys, and the boys can be distracting for the girls. The foundation has already been laid in fifth grade for a possible future mathematics gender gap among her students. If the difference has already been seen in the researcher's fifth grade classroom, it makes the researcher wonder how much earlier the difference can be detected.

If the difference is already apparent to the author's fifth grade female students, the possibility of a gender gap appearing in achievement in the future is highly likely. Can something be done in order to prevent this divide from occurring? The author feels that single-gender math classes may be the answer for her female students. As one can see from the results of the study, the girls felt that not having the boys in class helped them to learn better. They felt more confident, felt like their grades improved, and they noticed they were not distracted as much in an all-girl setting. If the girls' confidence level can be improved by a single-gender setting, that is half the battle. As can be seen in previously conducted research in chapter two, when a girl's confidence level drops, so does her achievement levels. It would stand to reason that the converse of that would also be true: if a girl's confidence level improves, her achievement levels would improve. 
In the author's study, the girls felt that the single-gender classroom gave them more confidence. In the author's opinion, this is a great insight into how girls learn mathematics.

Many critics claim that single-gender classrooms are not fair to all of the students. The author once heard in a lecture that "fair" does not always mean that everyone gets the same, but everyone gets what he or she needs. Perhaps girls need a single-gender math class in order to make sure they receive the mathematics foundation they will need later in life.

The author does, however, have some reservations about implementing a singlegender math classroom. As stated earlier in chapter three, much research has pointed to the idea that even in single-gender classrooms, there seems to be the potential for bias that favors boys. In no way would the researcher want to have a classroom that would perpetuate a gender bias and only contribute to a mathematics gender divide. The purpose of this study was to identify how girls would best learn math. Although this project did not examine the impact a single-gender classroom had upon boys, the author does feel that this is indeed important and encourages more research to be done in this area.

The author also agrees with Lee, the AAUW, and others that educators and administrators need to be working together to ensure an excellent education for all students. They should be working together on making the necessary adaptations within 
their schools in order to make sure that learning for both genders is taking place. This would include but is not limited to small classes, rigorous curriculum, high standards, discipline, good teachers, and attention to eliminate bias. This is half the battle, in the author's opinion, in confronting the gender divide.

In retrospect, the author would have done a few things differently while conducting her research. First, the classes would be separated from the beginning of the year and would continue throughout the duration of the academic year. In the author's research, she noticed her students going through a transition time when leaving her classroom and entering her teaching partner's classroom. The boys coming into her classroom also went through a transition period. The author's students had gotten used to her teaching methods and style, and it appeared, to the author, that the students needed an adjustment period in order to get used to the new teacher and her style. This could have affected the results of the author's study, since the study was conducted over a brief period of time. Conducting the study over an entire academic year would reduce the effects any adjusting periods may have had on the results of the research.

Second, it would be beneficial to have the same teacher teach an all-girls mathematics class and also teach a coeducational class. This would eliminate any other outside factors that could influence the results of the research. For example, teaching methods, the teacher's enthusiasm for the subject, and the teacher's knowledge of the subject matter could all influence the outcome of the research. In the author's study, it was difficult to control these factors completely. Although the teachers attempted to use 
the same lessons as much as possible, the teachers' personalities are very different. The author is in her third year teaching the math cur riculum used at the school (Harcourt Brace), while her teaching partner was in her first year. Together, these factors that were uncontrollable by the author, could have affected the outcome of the study. By having the same teacher teach both a single-gender math class and a coeducational math class might perhaps reduce the effects of these uncontrollable factors.

Third, the author feels that the boys and their learning should also be examined. The purpose of this paper was to determine the impact the gender divide and its possible effects had upon the author's female students. The paper also researched the effects a single-gender math class had upon the author's fifth grade female students. However, this paper did not consider the impact the single-gender math class had upon the author's male students. Perhaps further study needs to be conducted to determine the impact single-gender math classes would have upon male students and their achievements and attitudes toward math.

Fourth, the author feels more research should be conducted. Most previously conducted research has taken place in middle and high school classrooms. It is possible that single-gender math classes could have a positive effect in elementary classrooms. However, more extensive research will need to take place in this area.

Our girls and our boys are our future. They are both important members of a society in which we attempt to teach our children that they can be anything they want to 
be. In order to make this dream a reality, educators need to make sure they are equipping all their students with the knowledge and educational foundation necessary for them to tackle their futures head-on. Educators have a responsibility to make sure this is occurring within each classroom. It is not the desire of the author to bring down one group of students (i.e. the boys) in order to level the playing field for the girls. It is the desire of the author to bring up the girls' levels of performance in mathematics in order to level the playing field. If our girls are being shortchanged in their education in mathematics or in any area, it is the educators' responsibility to make the necessary changes in his or her classroom to make sure all students are getting what they need. 


\section{APPENDIX A}

Dear Parents:

As many of you know, I am presently working toward my Masters of Education degree at Cedarville University. I am happy to say that, Lord willing and if I get that little paper completed, I will graduate in June.

Speaking of that little paper... I am currently working on my thesis. Part of the requirements for my thesis is to conduct a treatment or an experiment using my students. Now don't worry. I am not going to do anything strange like see what effects eating anchovies three times a day has on their spelling scores. Nor will I attempt to determine if there is any benefit to switching the brains of students. Hmmm...that would be interesting. What I am doing my thesis on is mathematics.

In order to protect my experiment's validity, I need to keep what I am measuring confidential until after the experiment. I can tell you that Mr. Schrenker has approved the treatment. I can also answer any questions privately that you may have.

What will this involve? Mrs. Heyob is working with me. What we will be doing starting Monday, March 4 is separating the fifth grade into two different math classes. The class I will be teaching will be all the fifth grade boys, and Mrs. Heyob will be teaching the girls. We will switch classes for approximately 45 minutes a day. The content will be the same and the instruction will not change (i.e. We will both teach math like we normally would.) The only thing that will change is the environment. (OK...you may know enough to guess where I am going with my thesis. If so, please do me the huge favor of not discussing it with your child. I really need to have a valid experiment. Thank you!) The classes will be separated for six weeks.

Prior to the separation, each student will be given a survey which will remain anonymous. They will have to answer a few questions like "What is your favorite subject at school, how would you describe your abilities in math, and what do you see yourself being when you grow up?" After the experiment is completed, they will fill out another survey to give their opinions about the way the math class was conducted. Both surveys are anonymous. The most 
identifying trait they must write is whether they are a boy or girl. If you would like a copy of the surveys, please don't hesitate to ask.

I appreciate your cooperation and your flexibility. I have already talked with both classes about the change. They, of course, are looking forward to helping Mrs. Dunlap with her project. :) Once again, if you have any questions, please do not hesitate to get in touch with me.

Thank you!

In Him,

Mrs. Dunlap 


\section{APPENDIX B}

DO NOT put your name on this paper.

Check ONE for each of the following questions:

1. Which are you?

girl

boy

2. What is your favorite subject in school?

$\begin{array}{ll}\text { reading } & \text { math } \\ \text { English } & \text { science } \\ \text { spelling } & \text { heritage }\end{array}$

3. Do you see yourself going to college?

Yes

4. What do you see yourself growing up to be?

$\begin{array}{ll}\begin{array}{l}\text { writer/author } \\ \text { scientist } \\ \text { teacher } \\ \text { nurse }\end{array} & \text { actor/actress } \\ \text { business person } \\ \text { computer programmer } \\ \text { doctor }\end{array}$

5. How would you describe your abilities in math?

I am really good at math. (better than most of my class)

I am pretty good at math. (better than some of my class)

I am OK at math. (in the middle of my class)

I am not good at math. (at the bottom of my class)

6. Do you like math? Why or why not 


\section{APPENDIX C}

DO NOT put your name on this paper.

Check ONE for each of the following questions:

1. Which are you?

girl

boy

2. What is your favorite subject in school?

reading

English
spelling

math

science

heritage

3. Do you see yourself going to college?

Y Yes

5. What do you see yourself growing up to be?

writer/author
scientist
teacher
nurse

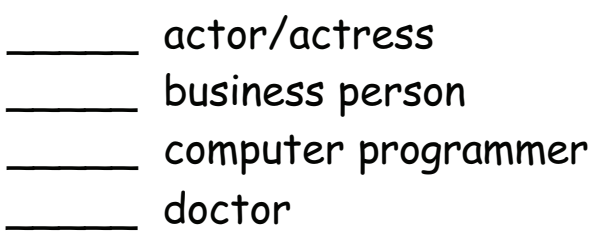

6. How would you describe your abilities in math?

I am really good at math. (better than most of my class)

I am pretty good at math. (better than some of my class)

I am OK at math. (in the middle of my class)

I am not good at math. (at the bottom of my class)

7. Do you like math? Why or why not?

8. Did separating the classes help you learn math better? Why or why not? (Use the back, if you need more room.) 


\section{APPENDIX D}

Grade: $5^{\text {th }}$

Topic: Adding Fractions

Goal: Students will demonstrate an understanding of fractions.

Objective: Students will be able to add and subtract fractions with like denominators and put the sums in lowest terms by using fraction pieces and by successfully completing ten problems independently using paper and pencil.

\section{Materials for each child:}

- math journals

- notebook paper and pencil

- fraction pieces (one bag for each pair)

- textbook

\section{Anticipatory Set:}

- Have students explore adding fractions together using the fraction pieces.

- Show the students how to write the number sentence to go along with what they are doing using the fraction pieces.

- Emphasize that the denominators do not change.

\section{Instruction:}

- Move from the concrete to the abstract by having students solve problems using only paper and pencil.

- Review how to put fractions into lowest terms.

Guided Practice: Have the students solve five math problems in their math journals. Have the students use the cooperative learning structure Pairs Check to solve the problems.

Sponge Activity: Have students make up their own problems and switch with their partner. Each one solves the problem and returns it to be checked.

Closure: Once they have completed their five problems, have student volunteers solve them on the board and teach the class what to do.

Independent Practice: Assign ten problems from the text to be solved independently (p.315 \#11-20).

\section{Evaluation:}

- observation

- partner work and board work (for some)

- homework 


\section{APPENDIX E}

b

Grade: $5^{\text {th }}$

Topic: Multiplying Fractions

Goal: Students will demonstrate an understanding of fractions.

Objective: Students will be able to multiply fractions and put their products in lowest terms by drawing pictures and then by using paper and pencil and successfully completing ten multiplication problems.

\section{Materials for each child:}

- math journals

- notebook paper and pencil

- white paper

- colored pencils, crayons, or markers

- textbook

- white board, marker, and eraser for each group

\section{Anticipatory Set:}

- Write an example multiplication problem on the board.

- Demonstrate the first fraction by drawing a box and shading in the appropriate fraction.

- Using the same box, shade in the other fraction, so that the two fractions overlap at an area.

- Show that where the colors overlap is the meaning of the multiplication sentence.

- Repeat the procedure two to three more times.

\section{Instruction:}

- Move from the concrete to the abstract by having students solve problems using only paper and pencil.

- Introduce canceling.

- Review how to put fractions into lowest terms.

Guided Practice: Have the students solve five math problems in their math journals. Have the students use the cooperative learning structure Numbered Heads Together to solve the problems.

Sponge Activity: Have students make up their own problems and switch with a partner. Each one solves the problem and returns it to be checked.

Closure: Once they have completed their five problems, have student volunteers solve them on the white board and share them with the class using Numbered Heads Together. 
Independent Practice: Assign ten problems from the text to be solved independently (p. 335 \#10-28 even).

\section{Evaluation:}

- observation

- partner work

- board work

- homework 


\section{APPENDIX F}

Grade: $5^{\text {th }}$

Topic: Polygons

Goal: Students will demonstrate an understanding of geometric shapes.

Objective: Students will be able to identify and define five geometric shapes based on the number of sides and angles each has and will successfully complete a worksheet while using toothpicks and marshmallows.

\section{Materials for each child:}

- math journals

- notebook paper and pencil

- 10 marshmallows and 10 toothpicks

- worksheet

- textbook

Anticipatory Set: Have students begin to explore making shapes using the toothpicks and marshmallows. Have them describe some of the shapes they have made.

\section{Instruction:}

- Define polygon. Explain that they will be learning about only some polygons.

- Have them make each shape using the toothpicks and marshmallows: triangle, quadrilateral, pentagon, hexagon, and octagon.

Guided Practice: As the students make their shapes, have them complete their worksheet.

Closure: Discuss the differences and similarities between the shapes. Have them find some in the classroom.

Independent Practice: Assign eight problems from the text to be solved independently (p. 117 1-8).

\section{Evaluation:}

- observation

- worksheet

- making shapes

- homework 
Name:

Number:

Date:

$\underline{\text { Math Worksheet }}$

\begin{tabular}{|c|c|c|c|}
\hline $\begin{array}{c}\text { Polygons } \\
\text { Pame of }\end{array}$ & $\begin{array}{c}\text { Number } \\
\text { of Sides }\end{array}$ & $\begin{array}{c}\text { Number of } \\
\text { Angles }\end{array}$ & $\begin{array}{c}\text { Picture of Your } \\
\text { Model }\end{array}$ \\
\hline Triangle & & & \\
\hline Quadrilateral & & & \\
\hline Pentagon & & & \\
& & & \\
\hline Octagon & & & \\
& & & \\
\hline
\end{tabular}




\section{APPENDIX G}

Grade: $5^{\text {th }}$

Topic: Solid Geometric Shapes

Goal: Students will demonstrate an understanding of geometric shapes.

Objective: Students will be able to identify and define six geometric shapes based on the number of sides, vertices, and edges each has and will successfully complete a worksheet while examining different geometric solids.

\section{Materials for each child:}

- math journals

- worksheet

- geometric solids

- text

Anticipatory Set: Have the students look around the room for solid shapes. Have them identify as many as they can.

\section{Instruction:}

- Review the terms edge, vertex, and side.

- Give each group a solid shape and allow them to attempt to identify the number of edges, vertices, and sides it has (triangular prism, triangular pyramid, square pyramid, cube, sphere, and cylinder).

Guided Practice: As the students explore their shapes, have them complete their worksheet.

Closure: Discuss the differences and similarities between the shapes. Discuss the worksheet and the differences and similarities between the shapes. Emphasize the differences in the cylinder and sphere.

Independent Practice: Assign nine problems from the text to be solved independently (p. 139 A-F and 6-8).

\section{Evaluation:}

- observation

- worksheet

- group work

- homework 
Name:

Date:

Number:

\section{Geometry Solid Shapes}

\begin{tabular}{|c|c|c|c|}
\hline Name & $\begin{array}{c}\text { Number of } \\
\text { Faces }\end{array}$ & $\begin{array}{c}\text { Number of } \\
\text { Vertices }\end{array}$ & $\begin{array}{c}\text { Number of } \\
\text { Edges }\end{array}$ \\
\hline Cube & & & \\
\hline Square Pyramid & & & \\
\hline $\begin{array}{c}\text { Triangular } \\
\text { Pyramid }\end{array}$ & & & \\
\hline $\begin{array}{c}\text { Triangular } \\
\text { Prism }\end{array}$ & & & \\
\hline Cylinder & & & \\
\hline
\end{tabular}




\section{APPENDIX H}

\section{GLOSSARY OF TERMS}

ACT: Americ an College Testing, Incorporation

\section{AAUW: American Association of University Women}

constructivist: an educational learning model which holds to the belief that children construct their own learning

CSP: Council for School Performance; organization founded to examine Georgia's math proficiency scores

ERIC: Educational Resources Information Center which can be accessed at http://ericir.syr.edu

ETS: Educational Testing Service

GRE: Graduate Record Exam

IMSA: Illinois Math and Science Academy

learned helplessness: when a student believes he/she is unable to do something; usually occurs as a result of an adult doing for the child instead of teaching him/her how to do something for him/herself

NAEP: National Assessment of Educational Progress

NOW: National Organization for Women

NSF: National Science Foundation

OhioLink: an educational database provided for students attending Ohio colleges and universities; http://www.ohiolink.edu

SAT: Scholastic Aptitude Test

scaffolding: refers to the procedure of helping a student reach a goal; in the educational setting, when a teacher supports a student through a task while reducing the amount of help provided until he/she is able to complete the task independently

TIMSS: Third International Mathematics and Science Study

Title IX: law passed in 1972 in order to abolish sex discrimination in public schools 
wait time: the amount of time a teacher allows before accepting an answer to a question; typically, it is less than one second 


\section{REFERENCES}

American Association of University Women. (1996). Smart efforts for girls in school. The Education Digest, February, 21-24.

American Association of University Women. (1998). Report finds separating by sex not the solution to gender inequity in school. Retrieved March 30, 2002, from http://www.aauw.org/2000/ssprbd.html

American Association of University Women. (1999). Gender gaps: where schools still fail our children. New York: Marlowe \& Company.

American Association of University Women. (2002). Single-sex education. Retrieved March 30, 2002, from www.aauw.org/1000/pospapers/ssedbd.html

Archer, J. (1998). Private coed schools find benefits in single-sex classes. Education Week, 17. Retrieved March 30, 2002, from http://www.edweek.org/vol-17/30coed.h17

Bauer, K. (1999). Promoting gender equity in schools. Contemporary Education, 71, $22-25$.

Bryan, C. (1997, June 3). Gender differences found in the way boys and girls solve math problems. Retrieved September 13, 2001, from http://www.apa.org/releases/math2.html

Council for School Performance. (2001). Gender differences in K-12 education: What indicators are important? Retrieved September 13, 2001, from http://www.arc.gsu.edu/csp/csp_gender.htm

Educational Testing Service. (2001). Differences in the gender gap. Retrieved January 19, 2002, from http://www.ets.org/research 
Family Education Network. (1999). Gender equity in math and science. Retrieved April 11, 2001, from http://familyeducation.com/article

Girls math/science education. The Education Digest, 63, 42-48. Retrieved April 11, 2001, from http://proquest.umi.com

Haag, P. (2000). K-12 Single-sex education: what does the research say? Champaign, IL: University of Illinois. (ERIC Document Reproduction Service No. EDO-PS00-9)

Karp, K. \& Shakeshaft, C. (1997). Restructuring schools to be math friendly to females. Bulletin, February, 84-93.

Lee, V. (1997). Gender equity and the organization of schools. In Bank, B. \& Hall, P. (Eds.), Gender, equity, and schooling (pp. 135-158). New York: Garland.

Levi, L. (2000). Gender equity in mathematics education. Teaching Children Mathematics, October, 101-105.

Matthews, C., Binkley, W., Crisp, L. \& Gregg, K. (1998). Challenging gender bias in fifth grade. Educational Leadership, December-January 1998, 54-57.

National Assessment of Educational Progress. (2001, August 2). Math report card. Retrieved September 20, 2001, from http://nces.ed.gov/pubsearch/pubsinfo.asp?pubid=2001518

Sadker, D. (1999). Gender equity: still knocking on the classroom door. Educational Leadership, April, 22-26.

Sadker, M. \& Sadker, D. (1994). Failing at fairness: how our schools cheat girls. New York: Simon \& Schuster. 
Sanders, J. (1997). Teacher education and gender equity. (Report No. RR93002015). (ERIC Document Reproduction Service No. ED408277)

Sanders, J. \& Peterson, K. (1999). Close the gap for girls in math-related careers. The Educational Digest, December, 47-49.

Schwartz, W. \& Hanson, K. (1992). Equal mathematics education for female students. (Report No. RR93002015). New York, NY: Institute for Urban Minority Education. (ERIC Document Reproduction Service No. ED344977)

Smith, I. (1996, July 19). Gender differentiation: gender differences in academic achievement and self-concept in coeducational and single-sex schools. Retrieved September 13, 2001, from http://alex.edfac.usyd.edu.au/LocalResource/studyl/coed.html

Spender, D. (1982). Invisible women: the schooling scandal. London: Writers and Readers.

Stainburn, S. (2000, January). All girls, all the time: February 1991. Retrieved March 30,2002 , from http://www.eduweek.org/tm/tmstory.cfm?slug=04feb91\&keywords=Stainburn Streitmatter J. (1999). For girls only: making a case for single-sex schooling. Albany: State University of New York.

Tiedemann, J. (2000). Parents' gender stereotypes and teachers' beliefs as predictors of children's concept of their mathematical ability in school. Journal of Educational Psychology, 92, 144-151.

Tschumy, R. (1995). What do we know about girls? Ensuring gender equity in the classroom. Bulletin, November, 58-61. 
Walliser, T. (1998). Separate but equal? Retrieved March 30, 2002, from http://abcnews.go.com/sections/living/DailyNews/single0312.html

Wiest, L. (2001). Selected resources for encouraging females in mathematics. The Mathematic Teacher, 94, 14-18. Retrieved April 11, 2001, from http://proquest.umi.com/pqdlink?

The Women's Freedom Network. (1997). Why "Take Our Daughter to Work Day"? Retrieved January 19, 2002 from http://www.womensfreedom.org/press97a.htm

The Women's Freedom Network. (1998). The untold story. The Women's Freedom Network Newsletter, 5. Retrieved January 19, 2002, from http://www.womensfreedom.org/artic514.htm

The Women's Freedom Network. (1998). Contrition feminist-style: the AAUW's 1998 report, gender gaps. The Women's Freedom Network Newsletter, 5. Retrieved January 19, 2002, from http://www.womensfreedom.org/artic563.htm 
VITA

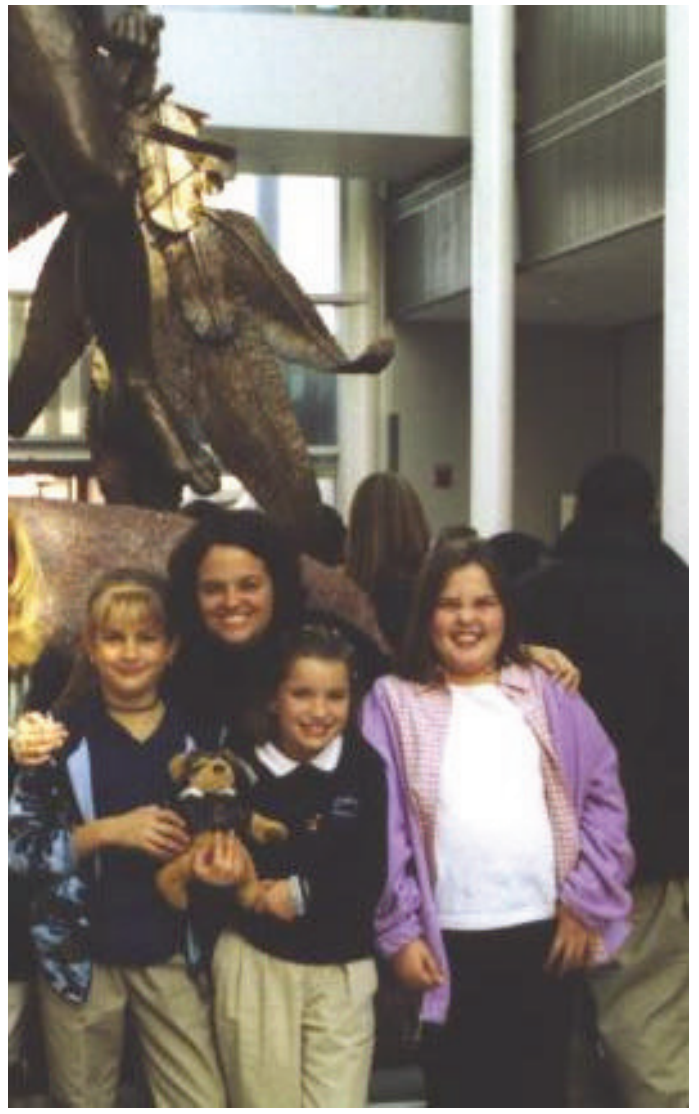

Celeste Elizabeth Dunlap grew up in Johnstown, Pennsylvania. She was saved at the age of six through the ministry of her jr. church leader. She was baptized a few years later. She graduated in 1989 from Johnstown Christian School and continued her education at Cedarville College. There she earned a B.A. degree in elementary education. After completing her degree in 1993, the Lord led her to teach at Phillipsburg Christian Academy in Phillipsburg, New Jersey where she taught second grade for two years. It was there that she met her wonderful husband, Craig. They were married in December, 1996. It was also right before the 1996-1997 school year that the Lord led them to Calvary Christian School in Covington, Kentucky. Celeste began substitute teaching there in January, 1997 and was offered a fifth grade position that fall. June, 2002 will mark the end of her fifth year teaching at Calvary. She is extremely excited to have also completed her Masters degree from Cedarville University.

Celeste is also very involved in her local church. She regularly attends Calvary Baptist Church in Covington, Kentucky. She has been involved in various ministries over the years such as Ladies Bible Studies, AWANA, the drama ministry, and working with the junior high youth. following email address: cncd@juno.com 